\title{
The Transcription Factor MIST1 Is a Novel Human Gastric Chief Cell Marker Whose Expression Is Lost in Metaplasia, Dysplasia, and Carcinoma
}

\author{
Jochen K. M. Lennerz, ${ }^{* \dagger}$ Seok-Hyung Kim, ${ }^{\ddagger}$ \\ Edward L. Oates, ${ }^{\star \S}$ Won Jae Huh, ${ }^{\star \S}$ \\ Jason M. Doherty, ${ }^{\star \text { पा }}$ Xiaolin Tian, ${ }^{\star \S} \|$ \\ Andrew J. Bredemeyer, ${ }^{\star \S \star *}$ James R. Goldenring, ${ }^{\dagger \dagger}$ \\ Gregory Y. Lauwers, ${ }^{\dagger}$ Young-Kee Shin, ${ }^{\neq \neq}$ \\ and Jason C. Mills`§ \\ From the Departments of Pathology and Immunology," and \\ Developmental Biology, and the Molecular Cell Biology \\ Program," Washington University School of Medicine, St. Louis, \\ Missouri; the Department of Pathology, ${ }^{\dagger}$ Massachusetts General \\ Hospital/Harvard Medical School, Boston, Massachusetts; the \\ Department of Pathology, ${ }^{\ddagger}$ Sungkyunkwan University, Samsung \\ Medical Center, Seoul, Republic of Korea; the Neuroscience \\ Center of Excellence," Louisiana State University Health Science \\ Center, New Orleans, Louisiana; Partners HealthCare System,** \\ Boston, Massachusetts; the Department of Surgery and \\ Developmental Biology, ${ }^{+\dagger}$ Epithelial Biology Center, Vanderbilt \\ University School of Medicine, Vanderbilt-Ingram Cancer Center, \\ Nashville Department of Veterans Affairs Medical Center, \\ Nashville, Tennessee; and the Department of Pharmacy, ${ }^{\#}$ Seoul \\ National University, Seoul, Republic of Korea
}

The lack of reliable molecular markers for normal differentiated epithelial cells limits understanding of human gastric carcinogenesis. Recognized precursor lesions for gastric adenocarcinoma are intestinal metaplasia and spasmolytic polypeptide expressing metaplasia (SPEM), defined here by ectopic CDX2 and TFF2 expression, respectively. In mice, expression of the bHLH transcription factor MIST1, normally restricted to mature chief cells, is down-regulated as chief cells undergo experimentally induced metaplasia. Here, we show MIST1 expression is also a specific marker of human chief cells. SPEM, with and without MIST1, is present in human lesions and, akin to murine data, likely represents transitional (TFF2 ${ }^{+}$/ MIST1 $^{+}=$"hybrid"-SPEM) and established (TFF2 ${ }^{+} /$ MIST1 $^{-}=$SPEM) stages. Co-visualization of MIST1 and CDX2 shows similar progressive loss of MIST1 with a transitional, CDX2 ${ }^{+}$/MIST1 $^{-}$hybrid-intestinal metaplasia stage. Interinstitutional analysis and compari- son of findings in tissue microarrays, resection specimens, and biopsies ( $n>400$ samples), comprising the entire spectrum of recognized stages of gastric carcinogenesis, confirm MIST1 expression is restricted to the chief cell compartment in normal oxyntic mucosa, rare in established metaplastic lesions, and lost in intraepithelial neoplasia/dysplasia and carcinoma of various types with the exception of rare chief cell carcinoma $(\sim 1 \%)$. Our findings implicate MIST1 as a reliable marker of mature, healthy chief cells, and we provide the first evidence that metaplasia in humans arises at least in part from the chief cell lineage. (Am J Pathol 2010, 177:1514-1533; DOI: 10.2353/ajpath.2010.100328)

The mainstays of therapy in gastric carcinoma are early recognition, resection, and neoadjuvant or adjuvant therapy. However, gastric cancer remains the second largest cause of cancer-related mortality worldwide, ${ }^{1}$ which drastically illustrates our lack of understanding of the sequence and progression of preneoplastic conditions. The traditional linear progression model of cellular changes, such as (Helicobacter-mediated) inflammation, atrophy, intestinal metaplasia (IM), dysplasia, and carcinoma, ${ }^{2-4}$ does not apply to all cases and does not allow incorporation of more recently recognized entities. For example, there are distinct types of IMs, not all carrying definitive preneoplastic potential, and some authors have argued that IM in general is a paraneoplastic condition because the earliest gastric carcinomas arise from gas-

Supported by J.C.M. (R01 DK-079798-01; ACS DDC-115769), X.T. (T32Al007172), A.J.B. (T32-CA009547), and J.R.G. (Department of Veterans Affairs Merit Review Award, RO1 DK071590). J.C.M. and J.R.G. were recipients of the AGA Funderburg Award in Gastric Biology Related to Cancer. Washington University Digestive Diseases Research Core Center, Bio-Bank and Clinical Data Core was supported by grant \#P30 DK52574.

\section{Accepted for publication May 25, 2010.}

Address reprint requests to Jason C. Mills, M.D., Ph.D., Department of Pathology and Immunology, Washington University School of Medicine, Box 8118, 660 South Euclid Ave, St. Louis, MO 63110. E-mail: jmills@wustl.edu. 
Table 1. Primary Antibodies and Staining Pattern

\begin{tabular}{|c|c|c|c|c|c|c|}
\hline Name & Host & Antigen characteristics & Clone or catalog no.; Source & IF; IHC 1: & Cell-type; Pattern & Reference \\
\hline MIST1 & $\mathrm{Rb} ; \mathrm{p}$ & $\begin{array}{l}\text { Synthetic human polypeptide } \\
\text { devoid of bHLH-/DNA }\end{array}$ & $\begin{array}{l}\alpha \text {-hMIST1-NOD-405; Jason C. } \\
\text { Mills, St. Louis, MO }\end{array}$ & $200 ; 400$ & CC, PIC; Nuclear & Present article \\
\hline Mist1 & $\mathrm{Rb} ; \mathrm{p}$ & $\begin{array}{l}\text { Synthetic polypeptide } \\
\text { corresponding to } 12 \mathrm{~N} \text { - } \\
\text { terminal AA of murine Mist1 }\end{array}$ & $\begin{array}{l}\alpha \text {-Mist1 2054; Stephen F. } \\
\text { Konieczny, West Lafayette, } \\
\text { IN }\end{array}$ & 250 & CC PIC; Nuclear & Pin et $\mathrm{al}^{17}$ \\
\hline CDX2 & $\mathrm{Rb} ; \mathrm{m}$ & $\begin{array}{l}\text { Synthetic polypeptide } \\
\text { corresponding to AA near } \\
\text { the } N \text { terminus of human } \\
\text { CDX2 }\end{array}$ & $\begin{array}{l}\text { ab76541 (Cell Marque Clone } \\
\text { EPR2764Y); Abcam, } \\
\text { Cambridge, MA }\end{array}$ & 100; 50 & Neg, IM; Nuclear & D'Amour et al ${ }^{18}$ \\
\hline TFF2 & Ms; m & $\begin{array}{l}\text { Carboxy-terminal human } \\
\text { spasmolytic polypeptide }\end{array}$ & $\begin{array}{l}\text { Sir Nicholas Wright; London, } \\
\text { UK }\end{array}$ & 10 & $\begin{array}{l}\text { MNC, SPEM, } \\
\text { Cytoplasmic }\end{array}$ & Elia et $\mathrm{al}^{19}$ \\
\hline CPB1 & $\mathrm{Rb} ; \mathrm{p}$ & $\begin{array}{l}\text { Full length human } \\
\text { carboxypeptidase B1 } \\
\text { protein }\end{array}$ & $\begin{array}{l}\text { H1360-D01P; Novus } \\
\text { Biologicals, Littleton, CO }\end{array}$ & 200 & CC; Cytoplasmic & Bunnett et $a^{20}$ \\
\hline H/K-ATPase & $\mathrm{Rb} ; \mathrm{p}$ & $\begin{array}{l}\text { Synthetic peptide from AA3- } \\
23 \text { of rat gastric } \mathrm{H} / \mathrm{K}- \\
\text { ATPAse }\end{array}$ & $\begin{array}{l}\text { HK9; Michael Caplan; New } \\
\text { Haven, CT }\end{array}$ & 1000 & PC; Cytoplasmic & $\begin{array}{l}\text { Gottardi and } \\
\text { Caplan }^{21}\end{array}$ \\
\hline PPSG & Sh; p & Full length human & ab9013; Abcam & 15,000 & CC; Cytoplasmic & Dennis et $\mathrm{al}^{22}$ \\
\hline MUC6 & Ms; m & $\begin{array}{l}\text { Synthetic peptide of human } \\
\text { gastric mucin tandem } \\
\text { repeat sequence }\end{array}$ & CLH5; ab49462; Abcam & 100 & $\begin{array}{l}\text { MNC, SPEM; } \\
\text { Cytoplasmic }\end{array}$ & Reis et $\mathrm{al}^{23}$ \\
\hline VEGFB & Gt; p & $\begin{array}{l}\text { Epitope mapping at the C- } \\
\text { terminus of human VEGFB }\end{array}$ & sc-1876; Santa Cruz & 100 & PC; Cytoplasmic & $\begin{array}{l}\text { Capoccia et al }{ }^{16} \text {; } \\
\text { Mills et al }{ }^{24}\end{array}$ \\
\hline GIF & $\mathrm{Gt} / \mathrm{R} ; \mathrm{p}$ & Full length recombinant & St. Louis, MO; David Alpers & $2000 / 10,000$ & PC; $;^{*}$ Cytoplasmic & Howard et al ${ }^{25}$ \\
\hline Gastrin & $\mathrm{Rb} ; \mathrm{p}$ & $\begin{array}{l}\text { Synthetic poplypeptide } \\
\text { corresponding to } N \\
\text { terminal } A A 1-13 \text { of human } \\
\text { gastrin }\end{array}$ & ab16035; Abcam & 200 & GC; ${ }^{\dagger}$ Cytoplasmic & $\begin{array}{l}\text { Stave and } \\
\text { Brandtzaeg }\end{array}$ \\
\hline CHRM & Ms; m & $\begin{array}{l}\text { Unprocessed central domain } \\
\text { AA145-245 of human } \\
\text { chromogranin }\end{array}$ & $\begin{array}{l}\text { LK2H10; Ventana Medical } \\
\text { Systems }\end{array}$ & Predil & ECL; ; Cytoplasmic & Degorce et al ${ }^{27}$ \\
\hline GS-II & N/A & Lectin; Griffonia simplicifolia-II & $\begin{array}{l}\text { Invitrogen and EY } \\
\text { Laboratories (San Mateo, } \\
\text { CA) }\end{array}$ & 1000 & $\begin{array}{l}\text { MNC, SPEM; } \\
\text { Cytoplasmic }\end{array}$ & Ramsey et $\mathrm{al}^{28}$ \\
\hline
\end{tabular}

CHRM, chromogranin; CC, chief cells; ECL, endocrine(-like) cells; GC, gastrin-producing cells (G-cells); GIF, gastric intrinsic factor; Gt, goat; IF, immunofluorescence; IHC, immunohistochemistry; m, monoclonal; MNC, mucous neck cell; Ms, mouse; Neg, not normally expressed in gastric unit; $p$, polyclonal; PIC, plasma cells; Predil, predilute (used as recommended); Rb, rabbit; and Sh, sheep.

${ }^{*}$ Stains parietal cells in human but chief cells in mouse (Figure $2 \mathrm{G}$ ).

${ }^{\dagger}$ Presence of predominantly gastrin ${ }^{+}$endocrine cells is indicative of antral-type mucosa. ${ }^{35}$

FPredominance of chromogranin ${ }^{+}$endocrine cells in the absence of G-cells is indicative of fundic-type mucosa.

tric, not intestinalized, glands. ${ }^{5-10}$ Also, traditional models do not take into account that atrophy of the corpus is almost always concomitant with pseudopyloric or spasmolytic polypeptide expressing metaplasia (SPEM; see below) $)^{11,12}$ and neglects evidence that this type of metaplasia may have closer links to eventual development of dysplasia or carcinoma. ${ }^{13}$ Recently, mouse models have argued for even more unexpected routes to the development of cancer, with a critical role of transdifferentiation of gastric epithelial cancer progenitors from migrating mesenchymal stem cells. ${ }^{14,15}$ All these lines of evidence argue strongly for fundamental changes in the way we interpret gastric carcinogenesis.

One limiting factor in the conceptualization of a more appropriate gastric carcinogenesis model is the dearth of reliable molecular markers for gastric epithelial differentiation in humans ${ }^{16}$ (Table 1). ${ }^{16-28}$ For example, the discovery of spasmolytic polypeptide (later renamed to trefoil factor 2 or TFF2) enabled recognition of ectopic TFF2-expression in the basal compartment of oxyntic mucosa known as SPEM. ${ }^{13,29,30}$ Normally, TFF2-expressing mucous neck cell progenitors in mid portion of the oxyntic mucosa differentiate into chief cells (TFF2-negative). ${ }^{31-33}$ This transition involves expression of the bHLH transcription factor MIST1, and genetic ablation in mice has demonstrated MIST1 as critically important for the structural features of the mature chief cell, including basal nuclear polarity and formation of large digestive enzyme containing granules. ${ }^{28,34}$ In animal models, chronic Helicobacter colonization induces loss of parietal cells (ie, oxyntic atrophy) and concomitant metaplasia of the basally located chief cells. ${ }^{11,31,35-37}$ Specifically, chief cells regain proliferative potential and start reexpressing progenitor markers such as TFF2, MUC6, and the epitope for the lectin Griffonia Simplificolia, GS-II. ${ }^{38}$ Thus, in animals, initial stages of SPEM are characterized by ectopic TFF2 expression in mature chief cells in addition to markers of normal chief cell differentiation (murine intrinsic factor, Pepsinogen C [PGC]; Carboxypeptidase B [CBP1]; MIST1). ${ }^{11}$ Progression of early SPEM (ie, $\mathrm{TFF}^{+} / \mathrm{MIST}^{+}{ }^{+}$SPEM) leads to fully metaplastic chief cells that turn off expression of MIST $1^{11,31}$ as they lose their characteristic acinar exocrine secretory structure (ie, established SPEM is TFF2 ${ }^{+}$/MIST1). ${ }^{12,31}$ Thus, murine SPEM arises, at least in part, from a metaplastic chief cell lineage, and over time mice infected with Helicobacter sp. develop gastritis cystica profunda as well as dysplasia. ${ }^{14,37,39}$

These findings triggered demonstration of SPEM in humans ${ }^{11,29,30}$ and, importantly, cancer association rates clearly exceed those reported for IM. ${ }^{13}$ However, because lineage tracing and sequential analysis of differentiation cannot be easily performed in humans, ${ }^{31,40}$ the cellular origins of human SPEM have not been established. Given the paucity of molecular tools to study the 
progression of lesions in human gastric carcinogenesis ${ }^{16}$ and that MIST1 expression has been a reliable marker for tracing the cellular origins of metaplasia in mice, we decided to investigate MIST1 as a biomarker of gastric differentiation in humans. We demonstrate that MIST1 is restricted to the normal human chief cell compartment and is lost during progression toward gastric cancer. Moreover, using a gastric tissue microarray (TMA) comprising hundreds of normal, metaplastic, dysplastic, and neoplastic tissue, we observe that MIST1 is expressed in all normal oxyntic-type samples but lost in adenocarcinoma. In short, our results demonstrate that MIST1 expression correlates with gastric mucosal health. Examination of MIST1 in IM and SPEM indicates that metaplasia strongly correlates with alterations in chief cell differentiation. These findings are in accord with animal data and thus indicate that metaplasia in humans might, at least in part, arise from transdifferentiation of the chief cell lineage. Until now, the chief cell compartment has been neglected in the assessment of intact gastric glandular differentiation. Our results argue for using MIST1 staining as an aid in the assessment of intact oxyntictype mucosa in clinical practice.

\section{Materials and Methods}

\section{Regulatory Approval}

The Human Studies Committee at Washington University Medical Center approved testing of all human aspects of this study, including examination of existing pathological specimens as well as sampling of fresh gastric tissues obtained postoperatively. The Washington University School of Medicine Animal Studies Committee approved all animal procedures. The ethics committee of the institutional review board of Chungbuk National University Hospital approved tissue microarray studies.

Generation of Mist1-eGFP plasmid was performed by using the restriction site-free PCR method of ribocloning. ${ }^{41,42}$ The coding region of hMist1 cDNA (Open Biosystems, Huntsville, AL; Image ID: 8322448) followed by a 30 amino acid peptide linker was added in-frame to the amino terminus of EGFP in pEGFP-C1 (Clontech Laboratories, Inc., Mountain View, CA) by the restriction site-free PCR method of ribocloning ${ }^{41,42}$ by using Klentaq-LA enzyme (Wayne Barnes, Washington University) and accurate PCR conditions. The riboprimers (ribose base, lowercase) used did not match the vector or target products, so they were first elongated on longer bandaid primer templates. PCR was performed on the vector region by using primers DNA3as; 5'-GGCAATTCCACCACACTGGACTAGt-3' and pEGFP-DNA3sb; 5'-CGCTACCGGTCGCCAC CACTAGTCCAGTGTGGTGGAATTGCC-3' with V5s; 5'-GGTAAGCCTATCCCTAACCCTCTC-3' and EGFP-V5asb 5'-CTCCTCGCCCTTGCTCACCATGAGAGGGTTAGGFGATAGGCTTACC-3' on pEGFP-C1 DNA. The hMIST1 target was PCR amplified by using DNA3s; 5'-ACTAGTCCAGTGT GGTGGAATTGCc-3' and hMIST1-DNA3b, 5'-GGGGCCGGTTCTTGGTCTTCATAACGGCAATT CCACCACACTG GACTAGTG-3' with V5as; 5'-GAGAGGGTTAGGGATAGGCTTACc-3' after sequential elongations on bandaids
hMIST1-V5b3; 5'-GAGGGCCCGCGGTTCGAAGGTAA GCCTATCCCTAACCCTCTC-3', hMIST1-V5b2; 5'-CTGCAGATATCCAGCACAGTGGCGGCCGCT CGAGTCTAGAGGGCC CGCGGTT-3', and hMIST1-V5b1; 5'CAGCTTCCGAGAGGGCACCA AGGGCAATTCTGCAGATATCCAGC-3'. The construct coding region pMT6-5 was verified by DNA sequencing.

\section{Homology Determination}

Class II bHLH protein sequences were retrieved from publicly available databases (National Center for Biotechnology Information, Swissprot) and aligned by using Vector NTI (Invitrogen, Carlsbad, CA) to determine where MIST1 shows the highest homology with other class II bHLH transcription factors (Figure 1). To minimize potential cross-reactivity with other bHLH transcription factors, we generated an RFP-EK-hMIST1 devoid of amino acids (AA) 81-127 (see below).

\section{Generation of RFP-EK-hMIST1 Construct}

The RFP-EK-hMIST1(lacking AA 81-127) construct (MT25-2) was made in three ribocloning steps. ${ }^{42}$ First an enterokinase (EK) cleavage (DDDDK) site was added to the $\mathrm{C}$-terminus of a N-terminal His-tagged and mutagenized ds-Red Escherichia coli expression vector (pWB536 ${ }^{43}$ ) by using riboprimers V4139-26rc (5'-GCTTTCTTCCCTTCCTTTCTCGCCA-riboC-3') and T4164-26rc (5'-GTGGCGAGAAAGGAAGGGAAGAAAG-riboC-3') and bandaid RStuEKb (5'-GCCACCACCTgT TCCTcgecgacgatgacgaCaaggcctGCTTTCTTCCCTTCCTTTCTCV) that adds a unique Stul site along with the EK site. Next, this plasmid (MT19-1) was cut with Stul and PCR amplified with riboprimers V4139-26rc and REKas (5'-GTCGTCATCGTCGGCGAGGAA-riboC-3') to fuse proteins to the $\mathrm{C}$-term of the EK site. The entire hMIST1 coding region was added by PCR amplifying with riboprimer REKs (5'GTTCCTCGCCGACGATGACGA-riboC-3') and bandaid hMIST1-EKRb (5'-TGGGGGCCGGTTCTTGGTCTTCTTGTCGTCATCGTCGGCGAGGAAC-3') along with riboprimer T4164-26rc and bandaid (5'-CGTCGTGACAGCAGCATCCAGTAGGCTT TCTTCCCTTCCTTTCTCGCCAC-3') using a hMIST1 CDNA plasmid template (Image ID-8322448). Annealed ribonuclease-treated PCR products were electroporated into BL21-ZYM cells (gift of Wayne Barnes). Positive clones were selected for their red color with UV (earlier) or visible light (later) on lactose containing autoinducing ZYM-505-Amp100 $\mu \mathrm{g} / \mathrm{ml}$ plates. EcoRV restriction pattern, DNA sequences, and NUPAGE-MES gels (Invitrogen) were used to confirm DNA, sequence, and protein size of the construct. Based on sequence alignment (Figure 1), AA 81-127 were removed from this hMIST1 plasmid (MT22-1) by a two-step PCR. In the first step an N-term fusion region and secondly, a C-term region lacking AA 18-127 was amplified in separate tubes by using the REKs riboprimer and the antisense bandaid hMISTNoDas (5'-CTGCTGGACATGGTCAGGATGGTCTGGATGCTGCTGTCACGACG-3') that spans the deletion in one and the T4164-26rc ri- 

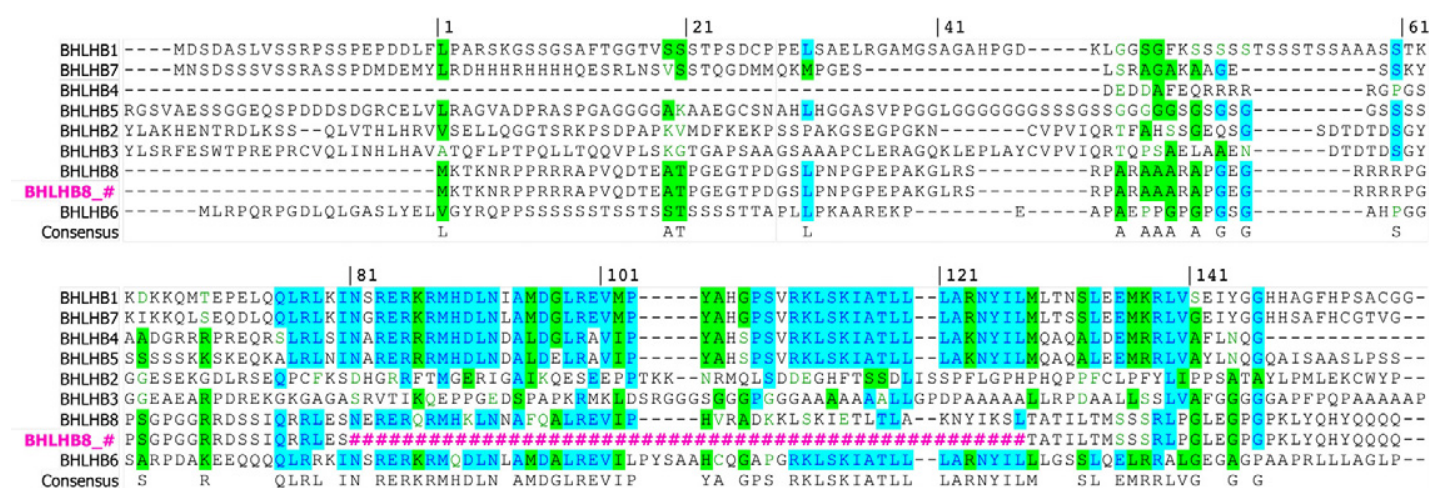

$\mid 161$

$\mid 181$

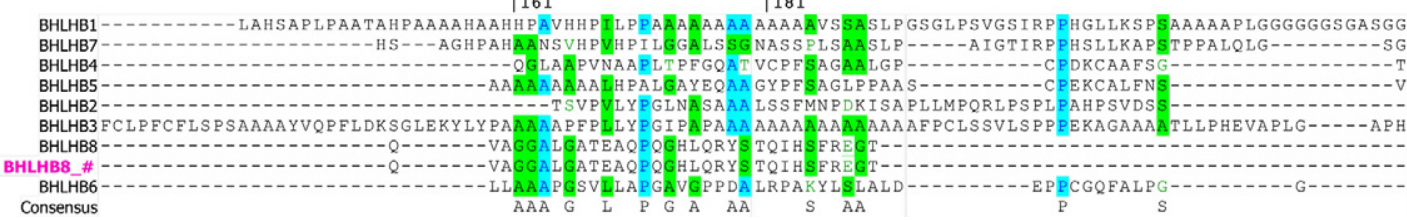

Figure 1. Sequence alignment of class II bHLH transcription factors to design immunogen with minimal cross-reactivity. Alignment is ordered by unweightec clustering according to sequence similarity. Amino acid position corresponding to complete BHLHB8 (MIST1, also known as BHLHA15) sequence is indicated on top. Gaps of alignment are marked by hyphen, amino acids are highlighted in turquoise when more than $50 \%$ conserved across proteins, highlighted in green when representing similar amino acids and displayed as green font when weakly similar to consensus sequence (last row); region omitted from MIST1 immunogenic peptide by ribocloning is indicated by pink pounds (labeled BHLB8_\#).

boprimer and the sense primer hMISTNoDs (5'-cgtcgtgacagcagcatccagACCATCCTGACCATGTCCAGCAG-3') spanning the deletion in the second. After eight cycles using BssHI cut MT22-1 as template, the tubes were mixed and diluted 1:10 in a new PCR reaction that had only REKs and T4164-26rc riboprimers. The resulting 454-bp product was then ribocloned into the same plasmid region used for MT22-1 above; all constructs were verified by DNA sequencing.

\section{Human Anti-MIST1 Antibody Generation}

An anti-human-MIST1 rabbit polyclonal antibody (hMIST1NOD-405) was made by immunizing rabbits (Covance Immunology Services, Denver, PA) with the N-His7-red fluorescent protein-enterokinase-hMIST1 fusion protein produced in E. coli $(25 \mathrm{ml})$ from the RFP-EK-hMIST1 (lacking AA 81-127) plasmid almost exclusively as inclusion bodies by autoinduction. ${ }^{44}$ Pelleted red inclusion bodies were solubilized in $\sim 5 \mathrm{ml}$ of $8.0 \mathrm{M}$ urea, $50 \mathrm{mmol} / \mathrm{L}$ Tris- $\mathrm{HCl} \mathrm{pH} 8.0$ buffer by heating to $50^{\circ} \mathrm{C}$. The soluble protein was diluted in half with binding buffer $(500 \mathrm{mmol} / \mathrm{L} \mathrm{NaCl}, 5 \mathrm{mmol} / \mathrm{L}$ imidazole, $20 \mathrm{mmol} / \mathrm{L}$ Tris $\mathrm{pH}$ 8.0) and bound to a $\mathrm{NiCl}_{2}$ charged iminoacetic acid-agarose column (Sigma-Aldrich Co., St. Louis, MO) that was washed with $500 \mathrm{mmol} / \mathrm{L} \mathrm{NaCl}, 20$ $\mathrm{mmol} / \mathrm{L}$ imidazole, $\mathrm{pH}$ 8.0, and eluted with $500 \mathrm{mmol} / \mathrm{L}$ $\mathrm{NaCl}, 100 \mathrm{mmol} / \mathrm{L}$ imidazole, $\mathrm{pH}$ 8.0. Antisera from multiple bleeds were tested for titer and specificity by using enzymelinked immunosorbent assay to the immunogen peptide as well as Western blot against cells stably expressing MIST1 (Figure 2A).

\section{Patient Samples}

The study includes analysis of a total of 459 de-identified samples comprising 128 samples from the Lauren $\mathrm{V}$.
Ackerman Laboratory of Surgical Pathology at BarnesJewish Hospital (Washington University Medical Center, St. Louis, MO) and 331 samples from the Department of Pathology of Chungbuk National University Hospital, Seoul, Korea. US samples consisted of two study sets: 90 resection samples (including four fast-fixed normal stomach samples) and 38 samples in the biopsy set. The fast-fixed normal stomach samples were derived from one autopsy (myocardial infarction, postmortem time 4 hours), two prophylactic gastrectomies, and one gastrectomy as part of a Whipple procedure for pancreatic adenocarcinoma (stomach not involved). Resection samples were selected via text queries of original pathological diagnosis recorded in the pathology laboratory information system (2000-2007). After review, the following samples were included as the resection set: no histopathological abnormality (oxyntic $n=7$; antrum $n=8$ ); fundic gland polyp ( $n=3$ biopsies); hyperplastic polyp ( $n=4$ biopsies); chronic active gastritis $(n=10)$, atrophy $[n=4$; included as SPEM $(n=3)$ and IM $(n=1)$, see diagnostic criteria], intestinal metaplasia $(n=15$; see below), (pseudo-)pyloric metaplasia ( $n=2$; see below); low-grade intraepithelial neoplasia/dysplasia $(n=3)$; high-grade intraepithelial neoplasia/dysplasia $(n=3)$, intestinal-type adenocarcinoma ( $n=18$; including three early gastric carcinoma), diffuse-type (signet ring cell) carcinoma $(n=5)$.

The biopsy set comprised 38 consecutive oxyntic samples with chronic active and chronic inactive gastritis, selected as consecutive samples from routine biopsy material ${ }^{45}$; clinicopathologic characteristics (eg, Diagnosis, Helicobacter pylori status) and 3-year-follow up were available. Samples from cardia and oxynto-antral transitional type mucosa were excluded and oxyntic origin was determined morphologically (proportion of pit to gland ratio and parietal cells) as well as by chromogranin- and 
A

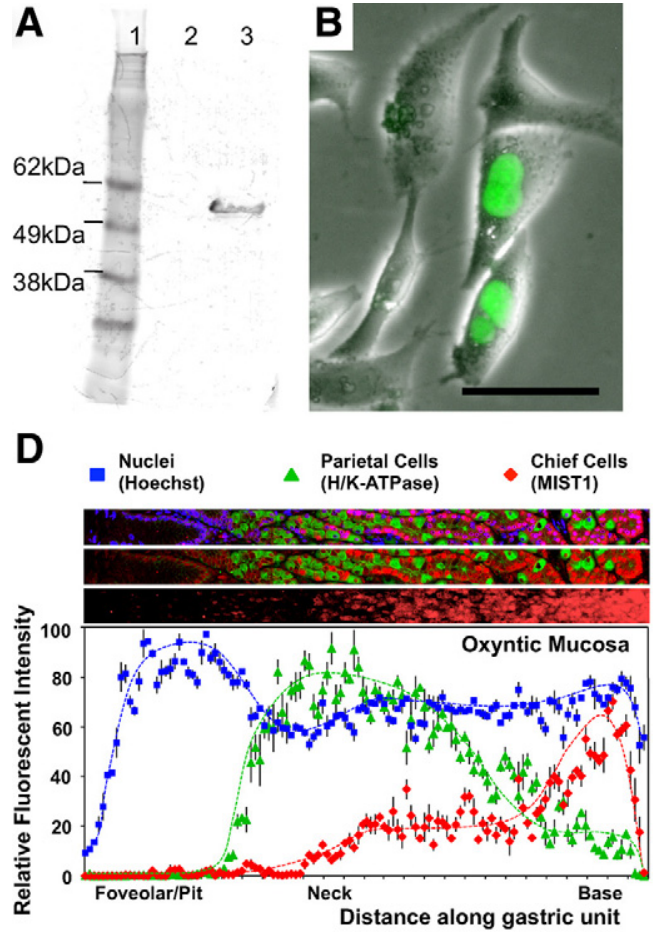

C

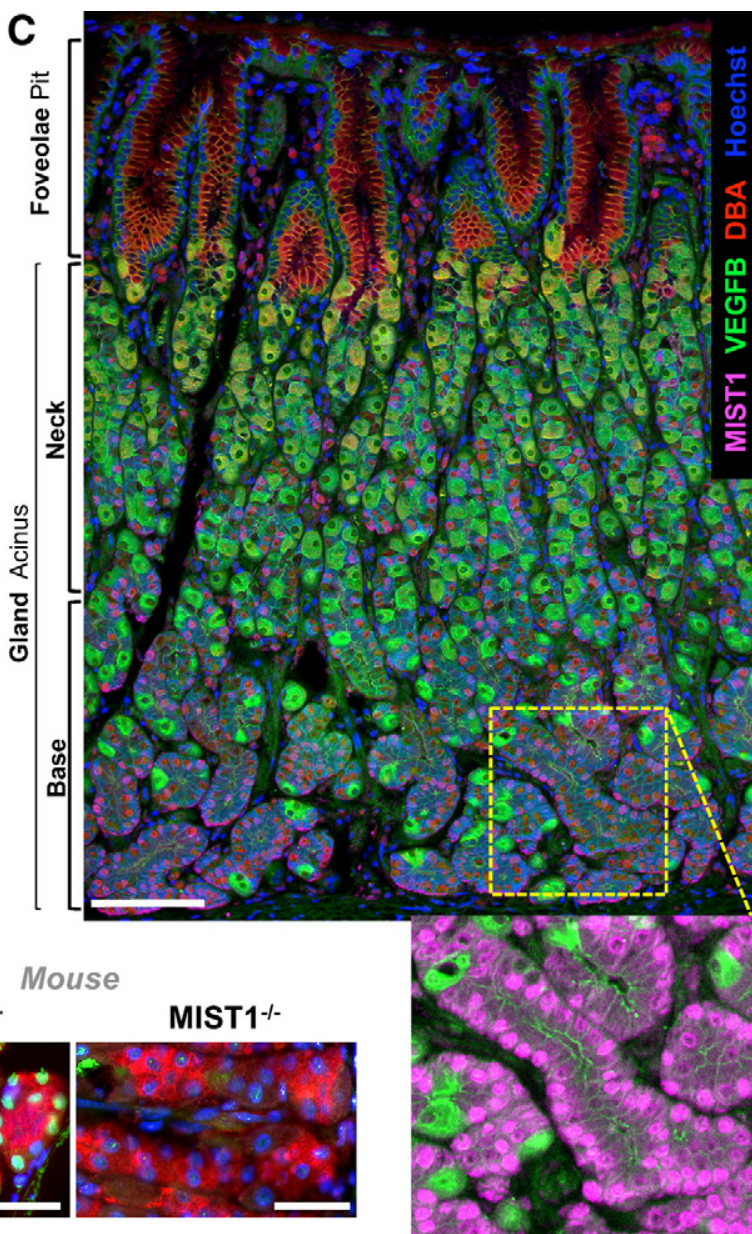

Figure 2. New rabbit-anti-human MIST1 antibody is a specific marker for human zymogenic (chief) cells. A: Western blot from HGC cells transfected with eGFP alone (lane 2) and with the MIST1-eGFP construct (lane 3$)$; the latter shows a single band with the expected molecular weight $(\sim 50 \mathrm{kD}=\mathrm{MIST} 1+\mathrm{eGFP})$ when compared with the size-control (lane 1). B: HGC-27 cells transiently transfected with the MIST1-eGFP construct show nuclear eGFP fluorescence. C: Normal human gastric mucosa with lumen at top. Luminal surface (foveolar or pit) cells are labeled with conjugated lectin DBA (Alexafluor-594, red), parietal cells in the neck-zone with VEGFB (Alexafluor-488, green), and nuclei with Hoechst 33258 (blue). The rabbit anti-human MIST1 antibody (Alexafluor-647, magenta) stains exclusively nuclei at the base of the gastric unit corresponding to chief cells. The inset demonstrates round, basally located MIST1-positive nuclei. Few

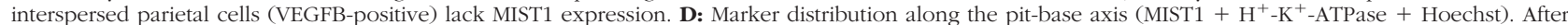
orientation, merged channels (top) were separated (eg, middle) and subsequently merged by using a customized pixel algorithm that also allows visualization (bottom). Merged images of at least 45 gastric units were quantified and are plotted as relative fluorescent intensity after normalization to the brightest pixel. Note that parietal cells concentrate in the neck (midportion) of the unit, whereas MIST1 ${ }^{+}$chief cells cluster at the base. E: Antral-type mucosa shows no epithelial MIST1 expression. Inset shows pyloric-type glandular cells with basal and flat MIST1-negative nuclei; arrow shows MIST1-positive plasma cells that serve as internal positive controls. F: The rabbit-anti-human MIST1 antibody also demonstrates chief-cell specific staining in oxyntic-mucosa of the mouse ( Mist $\left.1^{+/+}\right)$that is absent in Mist $^{-1-}$-animals. Scale bars $=20 \mu \mathrm{m}$ in $\mathbf{B}$, inset in $\mathbf{E} ; 100 \mu \mathrm{m}$ in $\mathbf{C}$ and $\mathbf{E}$; and $50 \mu \mathrm{m}$ in $\mathbf{F}$.

gastrin-immunostaining according to established protocols ${ }^{46}$; see Table $1 .{ }^{16-28}$

\section{Tissue Microarray (Korea)}

De-identified, archival cases of gastric carcinoma and related conditions on seven formalin-fixed paraffin embedded TMAs were analyzed for their expression of MIST1. Details of the arrays have been previously published. ${ }^{47}$ Briefly, samples were originally diagnosed by two of the authors (S.H.K. and Y.K.S.) by using diagnostic criteria as stated below. Clinical information and follow-up were available and all patients underwent surgical operations but no previous adjuvant chemo- or radiation therapy. Each of the 12 arrays (total $=384$ spots) contained one tonsilar sample for orientation and as positive controls (see Results). Tissue cores that were missing, or otherwise uninterpretable, were not included in the analysis $(n=41)$, resulting in a total number of 331 cases. Thus, the microarray analysis consisted of 139 cases of adenocarcinoma, 73 cases of early gastric cancer, 14 cases of diffuse-type gastric cancer, 28 cases of high-grade dysplasia, 27 cases of low-grade dysplasia, 50 cases of intestinal metaplasia, 41 cases of chronic gastritis, and 37 cases of normal stomach.

\section{Diagnostic Criteria}

Diagnostic criteria applied here follow established morphological, histopathological, and immuno-phenotypic features. ${ }^{48-51}$ Normal fundic-type mucosa (also-known as oxyntic- or corpus-type mucosa) shows the following: (1) foveolar (pit) to gland ratio of $<1: 4$, (2) relatively 
straight, tubular glands with a mixture of (3) parietal/ oxyntic cells or parietal-cell markers in normal distribution and (4) chief/zymogenic cells or chief-cell markers in normal distribution, and (5) no Gastrin-positive endocrine cells. Parietal/oxyntic cells are located mainly in the upper half of the glandular compartment and are vaguely triangular (pyramidal) with the base located on the basement membrane, a round central nucleus with evenly distributed chromatin and deep-pink/eosinophilic cytoplasm on H\&E stained sections. Chief/zymogenic cells are cuboidal with a basally situated nucleus with one or more small nucleoli and pale purple-gray cytoplasm. Normal antral-type mucosa (also-known as pyloric- or prepyloric-type mucosa) shows the following: (1) foveolae (pit) to gland ratio $>1: 2$, (2) short coiled pyloric-type glands (see below) with (3) rare parietal/oxyntic cells (so-called antral-oxyntic mucosa or transitional mucosa), and (4) gastrin-positive endocrine cells (G-cells). It is uncommon to see chief/zymogenic cells in antral-type mucosa. Pyloric glands resemble duodenal Brunner's glands and the cuboidal to columnar cells show (1) illdefined borders with (2) a basally located, dense, oval to flat nucleus and (3) bubbly to foamy, pale (flocculent) pink/eosinophilic to clear cytoplasm on H\&E stained sections. Mucous neck cells show an irregular cone shape with the tip located toward the basement membrane, a basally located dense nucleus and apical (TFF2-positive) secretory granules. Mucous neck cells are present mainly in the fundic-type but also in the pyloric-type mucosa, are arranged in clusters or as single cells between parietal cells in the neck of the glandular units and in lesser numbers in the isthmic portion of the glands of both the fundic-type and also the pyloric-type mucosa. Gastritis was assessed by routine H\&E and definitions followed established principles. ${ }^{52,53}$ For statistical evaluation, we separated between active (chronic-active gastritis) and nonactive (chronic inactive) gastritis. H. pylori immunohistochemistry (IHC; prediluted polyclonal rabbitanti H. pylori antibody; Ventana Medical Systems, Tucson, AZ) or Steiner stains confirmed the presence of $H$. pylori in the biopsy set. ${ }^{45}$ Intestinal metaplasia was defined as replacement of gastric epithelial cells with small intestinal lineages, specifically, goblet cells or CDX2 expressing epithelial cells. SPEM was defined as the presence of mucosa that phenotypically resembled antrum (with TFF2 ${ }^{+}$basal cells) interspersed in anatomically corpus/fundic-type mucosa. Thus, we consider SPEM functionally indistinguishable from the term "pseudopyloric metaplasia," although the former has traditionally been defined based on TFF2 positivity and the latter has been defined by H\&E appearance. ${ }^{13,54,55}$ All samples identified by the search term "atrophy" represented "chronic atrophic gastritis." Although individual fundic glands in these cases also demonstrated regional nonmetaplastic atrophic gastritis [= oxyntic atrophy: as assessed in sections stained for $\mathrm{H} / \mathrm{K}$-ATPase and arbitrarily defined as a decrease in parietal cell density to less than $1 / 3$ of the gland length ( $=2 / 9$ of the total mucosal height)], all cases of "chronic atrophic gastritis" contained sizeable regions of complete replacement of fundic glands by either intestinal or pyloric-type glands. According to es- tablished definitions, ie, atrophy $=$ metaplasia ${ }^{51}$ cases were assigned based on their predominant metaplastic pattern (SPEM $=3 ; \mathrm{IM}=1$ ) to the corresponding metaplasias. Here, we define the term hybrid-metaplasia and refer to lesions that demonstrate a mixed pattern with either $\mathrm{MIST}_{1}{ }^{+} / \mathrm{TFF} 2^{+}$or $\mathrm{MIST}_{1}{ }^{+} / \mathrm{CDX} 2^{+}$. Fundic gland polyps are composed of cystically dilated and architecturally irregular fundic glands. Hyperplastic polyps are architecturally distorted, irregular, and cystically dilated and elongated foveolar epithelial lesions with foveolar cells that have abundant mucinous cytoplasm. Lowgrade intraepithelial neoplasia/dysplasia was defined as glands with minimal architectural distortion, lined by enlarged columnar cells with minimal or no mucin and homogeneously blue vesicular, rounded or ovoid nuclei without nucleoli. High-grade intraepithelial neoplasia/ dysplasia was defined as crowding and branching glands without stromal invasion but pleomorphic, hyperchromatic, cigar-shaped nuclei with prominent amphophilic nucleoli. ${ }^{56}$ Invasion into the lamina propria is diagnostic of carcinoma, and we distinguished between intestinal- and diffuse-type carcinoma, whereby the former has recognizable glands and the latter consists of poorly cohesive cells diffusely infiltrating the gastric wall with little or no gland formation ("signet-ring cell tumor"); other morphological variants were not included. Early gastric cancer is by definition limited to the mucosa or submucosa, regardless of nodal status. Differentiation and TNM staging was assessed according to the proposed guidelines by the World Health Organization ${ }^{48}$ and the system established by the American Joint Committee on Cancer, ${ }^{49}$ respectively.

\section{Fixation}

Fast-fixed specimens were obtained fresh, pinned down, and sectioned parallel to the lesser curvature according to a predefined map. Alternate 2- to 3-mm thick sections of gastric wall from all anatomical regions were preserved snap-frozen in liquid nitrogen, or fixed either in $4 \%$ neutral-buffered paraformaldehyde (Merck, Whitehouse Station, $\mathrm{NJ}$ ) or in freshly-prepared methacarn fixative ${ }^{28}$; the latter was followed by transfer into absolute alcohol after 1 hour fixation. Specimens from all other study sets were originally fixed in $4 \%$ to $10 \%$ neutral-buffered formaldehyde and embedded in paraffin according to standard procedures. All paraffin-embedded specimens were cut at 3 to $5 \mu \mathrm{m}$, using conventional histological techniques and transferred to charged/silane- or glycine-coated slides (Sigma-Aldrich Co.).

\section{Immunofluorescence}

Sections were washed for 5 minutes (xylene $\times 3,100 \%$ ethanol $\times 2,95 \%$ ethanol $\times 1,70 \%$ ethanol $\times 1$, and PBS $\times 1)$. Sections were boiled in Trilogy (Cell Marque, Hot Springs, AR) for antigen retrieval, rinsed in de-ionized water for 15 minutes, and washed with PBS. ${ }^{57,58}$ Sections were blocked in $1 \%$ bovine serum albumin, $0.3 \%$ Triton X-100 PBS, incubated with combinations of the antibod- 
ies listed in Table 1, and visualized with appropriate secondary antibodies conjugated to Alexa 488 (green), 596 (red), 647 (magenta) -all 1:500-in combination with Hoechst 33258 staining (blue). Sections were mounted after PBS washes in glycerol:PBS.

\section{Immunohistochemistry (TMA)}

Sections were deparaffinized as stated above and subsequently immersed in $3 \% \mathrm{H}_{2} \mathrm{O}_{2}$ to quench endogenous peroxidase activity. Sections were microwaved for 20 minutes in $40 \mathrm{mmol} / \mathrm{L}$ borate buffer $(\mathrm{pH}$ 8.3) [or citratebuffer ( $\mathrm{pH}$ 6.0)] supplemented with $1 \mathrm{mmol} / \mathrm{L}$ EDTA and 1 $\mathrm{mmol} / \mathrm{L} \mathrm{NaCl}$ for antigen retrieval. ${ }^{59,60}$ Avidin and biotin were applied consecutively to prevent endogenous biotin related background staining. Sections were incubated with 1:100 rabbit-anti-human MIST1 for 60 minutes, followed by three successive rinses with $0.1 \%$ Tween-20 and incubation for 20 minutes with biotinylated goat antirabbit Abs (Dako, Glostrup, Denmark). After rinsing (0.1\% Tween-20), tissue sections were incubated with horseradish peroxidase-conjugated streptavidin (Dako) for 20 minutes at room temperature. Slides were washed (0.1\% Tween-20), and the chromogen was developed for 5 minutes with liquid 3,30-diaminobenzidine (DiNonA, Seoul, Korea) before counterstaining with Meyer's hematoxylin. After dehydration sections were mounted in Canada balsam.

\section{Immunohistochemistry (Other Than TMA)}

IHC staining was performed automatically with a Ventana Benchmark XT automated slides stainer (Ventana Medical Systems). The protocol consisted of a pretreatment with CC1, pH 8.0 (Ventana Medical Systems), followed by incubation with the primary antibodies at the indicated dilutions (Table 1). Antigen-antibody complexes were detected with an IVIEW-DAB (diaminobenzidine) detection system (catalog number 760-500; Ventana Medical Systems) including ultra View Universal DAB inhibitor, ultra View Universal HRP Multimer, ultra View Universal DAB Chromogen, ultra View Universal DAB $\mathrm{H}_{2} \mathrm{O}_{2}$, and ultra View Universal DAB Copper. For dual-color IHC, the ultra view Universal Alkaline Phosphatase Red Detection kit (catalog number 760-501, Ventana Medical Systems) including ultra View Red Alkalone Phosphatase, ultra View Red Enhancer, ultra View Red Naphthol, ultra View Red Fast Red A, and Fast red B were used. Standard protocols were modified to keep temperature at $37^{\circ} \mathrm{C}$ between washes and antigen retrieval; incubations with antibodies were also performed at $37^{\circ} \mathrm{C}$.

\section{Staining Controls}

For most antibodies the staining properties and specificity have previously been established, and the specific conditions and modifications of staining protocols are provided, when applicable (Table 1). Specificity of the $\mathrm{IHC/IF}$ reactions was verified by omission of primary and secondary antibodies and replacing them with Tris-buff- ered saline or normal serum, respectively. In case of the newly raised rabbit-anti-human MIST1 antibody, the specificity was assessed by using six different controls $^{31,34}$ : (1) examination of staining properties in murine oxyntic mucosa and comparison with previously established MIST1 antibodies ${ }^{28,61}$ (comparison control); (2) staining pattern of rabbit-anti-human MIST1 in Mist1 ${ }^{-1-}$ mice (knock-out control); (3) we performed pre-absorption controls with the MIST1 antibody (1:100) combined with the MIST1-RFP peptide (1:10), against which the antibodies were raised (preabsorption control); (4) the secondary antibody was used without primary antibody in the first incubation (negative control); (5) we performed normal serum controls by replacing the primary antibody by normal (rabbit) serum (normal serum control) using 1:10 and 1:20 concentrations; and (6) we examined specificity via Western blots of cell lysates (see below).

\section{Cell Culture, Transfection, and Western Blot}

Human gastric cancer (HGC) cell line HGC-27 (HPACC, Porton Down, UK) cells were maintained and stable MIST1-expressing lines generated as previously described. ${ }^{34}$ For Western blot, HGC-27 cells (otherwise MIST1-null) were transfected to stably express either MIST1-eGFP or eGFP alone (control). HGC-27 with stable expression of cytoplasmic eGFP were rinsed with ice cold PBS twice, harvested ( $\sim 10^{6}$ cells per experiment), and pelleted at $200 \mathrm{~g}$ for 5 minutes. The cell pellets were lysed in $400 \mu$ l of lysis buffer $(50 \mathrm{mmol} / \mathrm{L}$ Tris- $\mathrm{HCl}, \mathrm{pH} 7.5$, $150 \mathrm{mmol} / \mathrm{L} \mathrm{NaCl}, 1 \% \mathrm{NP} 40,1 \%$ sodium deoxycholate, Roche (Indianapolis, IN) protease inhibitor cocktail tablet), incubated at $4^{\circ} \mathrm{C}$ for 20 minutes, and then spun at 14,000 rpm for 20 minutes (all procedures performed on ice or at $\left.4^{\circ} \mathrm{C}\right)$. The supernatant was collected and mixed with $4 \times$ SDS loading buffer, boiled for 5 minutes, and separated by electrophoresis on a $4 \%$ to $12 \%$ NuPage gradient polyacrylamide gel (Invitrogen). Western transfer followed standard protocols with rabbit anti-human MIST1 (1:1000) and IRDye 800 conjugated donkey anti-rabbit IgG (Rockland, Gilbertsville, PA) to detect bands.

\section{Microscopy}

Initial analysis of $\mathrm{H \& E}$ and $\mathrm{IHC}$ was performed by using an Olympus AX70 epi-fluorescence microscope or Olympus BX51 light microscope connected to a 12 Mpixels Olympus DP70 digital camera (Olympus America, Center Valley, PA). For multicolor fluorescence, we used a Zeiss Axiovert 200 inverted fluorescence microscope (Zeiss, Maple Grove, MN) with photomicrographs obtained via Axiocam MRM camera with Apotome optical sectioning filter (output as TIFF files; 1.4 megapixel: $1388 \times$ 1040). TMA-, all IHC-, and routine-stained sections were scanned by using a Scancope XT system (Aperio, Vista, CA).

Histological evaluation consisted of five stages. (1) Independent evaluation by the original pathologists (United States/Korea) combined with case selection by four of the authors (United States: J.K.L. and J.C.M.; 
Korea: S.H.K. and Y.K.S.). (2) The fast-fixed study set was used to determine staining properties of all antibodies. This examination includes performance characteristics of the newly raised MIST1 antibody and review was performed by five of the authors (J.K.L., E.J.O., A.B.J., X.T., and J.C.M.). (3) TMA-staining, performed in Korea, was initially reviewed and evaluated by two of the authors (S.H.K. and Y.K.S.). (4) MIST1-stained TMA-sections were scanned and electronically separated into individual images by using a customized link between several software platforms (Adobe Photoshop CS3, Adobe Systems, San Jose, CA; Aperio ImageScope 10.0/TMALab; ImageJ version 10.2). Specifically, the link was created by using AutolT (version 3.2.12.0 by Jonathan Bennett), a freeware BASIC-like scripting language for automating the Microsoft Windows GUI. Subsequently, (5) images were evaluated by using an automated (ImageJ) threshold function. ${ }^{62}$ Examination of all visual data was performed by J.K.L. and J.C.M. and both independently selected representative regions, followed by circulation of electronic documents among all authors and final selection of photomicrographs.

\section{Quantification and Merging Functions}

Quantification was performed by using digital image processing via ImageJ (version 1.37v; http://rsb.info.nih.gov/ ij/, last accessed July 21, 2010) and Photoshop CS3 (Adobe Systems) according to previously established semiautomatic protocols. ${ }^{28,31,62}$ Briefly, for quantifications along the gastric units, three images containing at least 10 well-oriented gastric units were taken from each normal sample. Each channel was first converted into an eight-bit grayscale image. After manual isolation of gastric units, their height was normalized to 1388 pixels and all units overlaid (total number $=n$ samples $\times 30$ units per marker [three images $\times 10$ units]). To allow spatial projection of gastric units on top of each other and subsequent quantification of "optical summation" images, we multiplied the inverse of each pixel value of the merged image with the corresponding pixel value of the base image. The resulting color per merge is always lighter and visually similar to projecting slides on top of each other (black leaves the color unchanged and white produces white). Merged images were quantified along the foveolar-base axis (unitary axis) by using a binned pixel algorithm. Specifically, the mean fluorescence intensity for each line of pixels perpendicular to the unitary axis was extracted, providing 1388 data points (lines) that were averaged as bins of 10 lines, resulting in 139 values. After normalization to the brightest individual point in all images (set to 100), values were plotted as relative fluorescent intensity versus unitary (foveolar-base) axis. To enable merged-overlay of traditional IHC stains (ie, on subsequent levels), we first synchronized virtual slides, extracted and manually merged fields and then performed blending of layers by selecting only the darker pixel. Specifically, pixels lighter than the blend color are replaced and pixels darker than the blended color do not change.

\section{Statistical Testing}

Statistical analyses were conducted by using Fisher's exact test or Cohen's kappa, ${ }^{63}$ when appropriate. $P$ values of $<0.05$ were regarded as statistically significant. All data were analyzed by using Prism 5.0b (GraphPad Software Inc., La Jolla, CA), Microsoft Excel 2008 (version 12.1.9; Microsoft Corporation, Redmond, WA), or the online statistical toolbox of the Chinese University of Hong Kong by Professor A. Chang (http://department.obg.cuhk. edu.hk/researchsupport/statmenu.asp; last accessed July 21, 2010).

\section{Results}

We raised a new rabbit-anti-human MIST1 (also known as BHLHB8 or BHLHA15) antibody by combining bioinformatics and ribocloning approaches. Using publicly available databases (National Center for Biotechnology Information, Swissprot) we extracted and aligned class II bHLH protein sequences ${ }^{64-67}$ to determine the region of highest homology to MIST1 (Figure 1). To minimize crossreactivity with other $\mathrm{bHLH}$ proteins, we omitted the bHLH-/DNA-binding domain (amino acids 81-127) of human MIST1 by using a ribocloning strategy and immunized rabbits with the resulting recombinantly expressed protein hMIST1-NOD-405 (Figure 1, BHHLHB8_\#). Enzyme-linked immunosorbent assay and Western blot confirmed titers and reactivity against the recombinant protein (not shown). The antibody showed reactivity only against MIST1-transfected HGC-cells, confirming specificity (Figure 2A). MIST1-eGFP transfections demonstrate fluorescence signals restricted to the nucleus, confirming nuclear expression pattern of transfected human MIST1 (Figure 2B).

\section{MIST1 Expression in Normal Gastric Mucosa}

We used the newly raised rabbit-anti-human MIST1 antibody to study the immunostaining pattern in human oxynticand antral-type mucosa by using multiple approaches. Chief-cell specific expression was demonstrated via colocalization immunofluorescence (Figure $2 \mathrm{C}$ ). In addition, we used a merged-overlay pixel algorithm on synchronized virtual slides stained with conventional IHC to show that MIST1-positive cells on one section were also positive for the chief cell markers CBP1 and PGC on subsequent sections (not shown). Furthermore, quantification of mean fluorescent intensity across multiple gastric units [MIST1: $n=90$ units; $\mathrm{H}^{+} / \mathrm{K}^{+}$- ATPase: $n=78$ units; vascular endothelial growth factor B (VEGFB) $)^{16}: n=45$ units; Hoechst (nuclei): $n>90$ units] along the foveolarbase axis (unitary axis) by using a binned pixel algorithm (see Materials and Methods) demonstrated the highest density of MIST1 expression at the chief cell-populated base of the gastric unit (Figure 2D). In contrast, the parietal and foveolar (surface/pit) cell compartments do not express MIST1 (Figure 2, C and D). There was no MIST1 expression in any of the 14 antral samples (Figure $2 \mathrm{E})$, and no difference in MIST1 expression between 
Table 2. Overview of MIST1-Staining in Resection (RS) and Tissue Microarray (TMA) Specimen

\begin{tabular}{|c|c|c|c|c|c|c|c|c|}
\hline \multirow[b]{2}{*}{ Group } & \multirow[b]{2}{*}{ Subgroup } & \multicolumn{2}{|c|}{ RS (United States) } & \multicolumn{2}{|c|}{ TMA (Korea) } & \multirow[b]{2}{*}{$P$ value } & \multicolumn{2}{|c|}{ Total } \\
\hline & & $\mathrm{MIST}^{+} /$total & $\%$ & MIST1+/total & $\%$ & & $\mathrm{MIST}^{+}$ & $\%$ \\
\hline \multirow[t]{2}{*}{ Normal $^{\text {bs }}$} & Antrum & $0 / 8$ & 0 & 0/6 & 0 & 1.00 & $0 / 14$ & 0 \\
\hline & Fundus & $7 / 7$ & 100 & $16 / 16$ & 100 & 1.00 & $23 / 23$ & 100 \\
\hline \multirow[t]{2}{*}{ Polyps } & $\mathrm{FGP}^{*}$ & $3 / 3$ & 100 & - & - & - & $3 / 3$ & 100 \\
\hline & $\mathrm{HP}^{\star}$ & $0 / 4$ & 0 & - & - & - & $0 / 4$ & 0 \\
\hline Gastritis $^{\text {bs }}$ & CAG & $8 / 10$ & 80 & $16 / 31$ & 51.6 & 0.15 & $24 / 41$ & 58.5 \\
\hline \multirow{2}{*}{ Metaplasiabs } & SPEM $^{*}$ & $4^{\mathrm{dep} / 5}$ & 80 & - & - & - & $4 / 5$ & 80 \\
\hline & $\mathrm{IM}$ & $4^{\text {dep} / 16}$ & 25 & $6 / 34$ & 17.6 & 0.71 & $8 / 50$ & 16 \\
\hline \multirow[t]{2}{*}{ Dysplasia } & Low-grade & $0 / 3$ & 0 & $4 / 24$ & 16.6 & 1.00 & $4 / 27$ & 14.8 \\
\hline & High-grade & $0 / 3$ & 0 & $3 / 25$ & 12 & 1.00 & $3 / 28$ & 10.7 \\
\hline \multirow[t]{3}{*}{ Carcinoma } & $\mathrm{AdCa}$ & $0 / 13$ & 0 & $2 / 126$ & 1.6 & 1.00 & $2^{\mathrm{ccd} / 139}$ & 1.4 \\
\hline & EGC & $1 / 13$ & 7.7 & $0 / 60$ & 0 & 1.00 & $1^{\mathrm{ccd} / 73}$ & 1.4 \\
\hline & DT & $0 / 5$ & 0 & $0 / 9$ & 0 & 1.00 & 0/14 & 0 \\
\hline Total & & 90 & & 331 & & & 421 & \\
\hline
\end{tabular}

AdCa, intestinal-type adenocarcinoma; CAG, chronic active gastritis; DT, diffuse-type gastric carcinoma (signet-ring cell type); EGC, early gastric carcinoma; FGP, fundic gland polyp; HP, hyperplastic polyp; MIST1+, epithelial nuclear MIST1 positivity; $P$ values determined by two-tailed Fisher's exact test; RS, resection set; Total, sum of RS and TMA.

${ }^{*}$ Not assessed in TMA specimen.

${ }^{b}$ Also assessed in biopsy set (Table 3; Figure 5).

${ }^{\mathrm{ccd}}$ Corresponds to very rare chief-cell differentiation [observed in 3 of 226 carcinomas $(\sim 1.3 \%)$ ].

depDistinct expression pattern in adjacent gastric units of SPEM and IM with or without TTF2 and CDX2, respectively (Figure 4, J and K; 5C; 6, $D$ and $E)$.

samples stained in labs in the United States and those stained in Korea was noted (Table 2). Moreover, the newly developed MIST1 antibody labeled chief cells in mice with no colocalization in GS-II (mucous neck) or VEGFB-positive (parietal) cells but with colocalization with gastric intrinsic factor, a chief cell-specific marker in mice (Figure 2F). As expected, Mist1 ${ }^{-1-}$ mice showed no reactivity (Figure $2 \mathrm{~F}$ ). Similarly, the omission of the primary or secondary antibody as well as preabsorption and normal serum controls showed absence of staining, whereas reversal of fluorophores as well as comparison of immunoperoxidase and immunofluorescence staining showed identical expression pattern (Figure 2, C-E, and not shown). Thus, epithelial MIST1 expression in humans, as in mice, is restricted to chief cells. ${ }^{28,31}$

In addition to epithelial labeling, we noted nuclear MIST1 staining in plasma cells in the lamina propria. Colocalization studies demonstrate strong cytoplasmic Syndecan/CD138-positivity in these cells (Figure 3A), additionally confirmed by in situ hybridization for kappa and lambda light-chains on adjacent sections (Figure 3B). As plasma cells were present in all stomach sections, the plasma cell staining serves as an internal control (ie, when epithelial-MIST1 is lost) as well as a marker for the degree of chronic inflammation (eg, Figure $3 \mathrm{C}$ ). A more detailed study of MIST1 in plasma cells is in preparation (Mills et al, unpublished observations).

\section{MIST1 Expression in Hyperplastic and Inflammatory Gastric Lesions}

We next used MIST1 to label a spectrum of human lesions separated in diagnostic groups in a multi-institutional/national setting (Table 2). First, we assessed immunostaining in 10 samples of a gastric resection set with previously diagnosed chronic active gastritis (United States) and found normal MIST1 labeling in 8 of 10 cases.
The remaining two cases showed multifocal absence of MIST1 in areas of deep glandular damage, as identified by intraepithelial neutrophils with or without epithelial cell degeneration or loss. In both cases, the deeper, nondamaged glandular aspects as well as the surrounding nondamaged mucosa still showed preservation of normal MIST1 labeling. The proportion of MIST1 staining in the cases of chronic-active gastritis in another set of cases collected in the Republic of Korea and assembled on a TMA was slightly lower (51.6\%); however, statistical comparison showed no discernable difference $(P=0.15$, Fisher's exact test), and MIST1 negativity was likely increased due to more limited tissue sampling per case in a TMA core. The TMA-core gastritis set included a more heterogeneous spectrum of diagnoses with active, chronic nonactive, and chronic gastritis. The overall pattern across all inflammatory lesions was that 17 of the 31 cases ( $55 \%$ ) showed at least focal MIST1 loss in areas of deep glandular damage. We also examined a third set comprising 25 oxyntic biopsy samples (United States) with chronic active gastritis (18 H. pylori-positive) and nine samples of chronic inactive gastritis (lack of neutrophils; all H. pylori-negative); these showed neither association of MIST1 labeling with activity status (Table 3A) nor association of MIST1 labeling with $H$. pylori status (Table 3B). In total, we determined MIST1 labeling in 75 cases of gastritis, 20 of which showed focal loss of MIST1 in areas of deep glandular damage. Superficial damage was not associated with loss of MIST1. The resection set (United States) also contained seven benign polyps, and we found isolated MIST1-positive nuclei in deeper aspects of cystically dilated gastric units in the three examined fundic gland polyps (Figure 3D). In contrast, all four examined hyperplastic polyps showed no MIST1 staining in the expanded foveolar epithelial compartment (Figure 3E). 

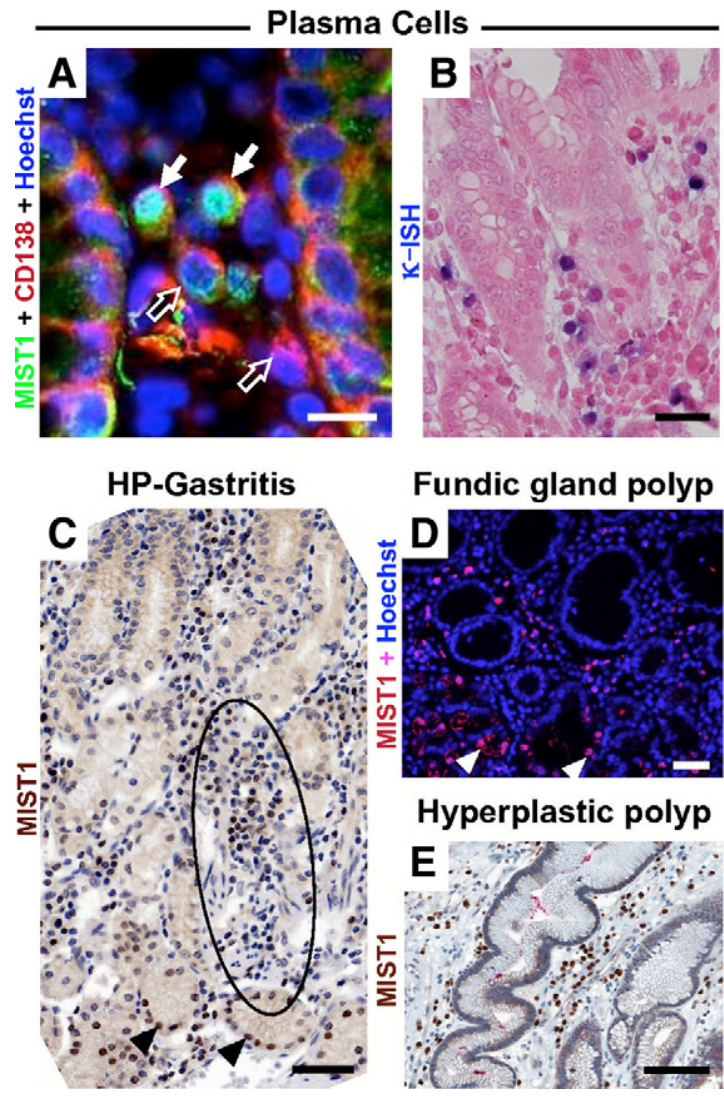

Hyperplastic polyp

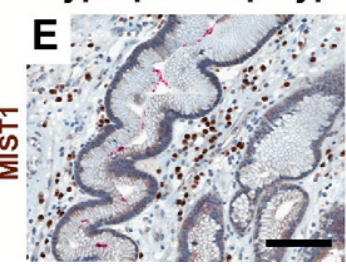

Figure 3. MIST1 in plasma cells, gastritis and gastric polyps. A: Lamina propria shows colocalization of nuclear MIST1-staining (green) and Hoechst (blue), resulting in the merged color turquoise in CD138-positive (syndecan, cytoplasmic, red) plasma cells (arrows). Note that not all CD138-positive cells are MIST1-positive (open arrows). B: Presence of plasma cells confirmed by in situ hybridization of kappa and lambda (not shown) on a subsequent tissue section. C: Helicobacter pylori (HP) gastritis (= chronic active gastritis) with deep glandular injury (region of intraepithelial neutrophils and plasma cells in mesenchyme encircled) demonstrates preserved nuclear MIST1-expression in basal cells (arrowheads). D: Individual MIST1 positive nuclei (arrowheads) in cystically dilated fundic glands. E: Fundic hyperplastic polyp is MIST1 negative. Scale bars $=20 \mu \mathrm{m}$ in $\mathbf{A} ; 50 \mu \mathrm{m}$ in $\mathbf{B}$ and $100 \mu \mathrm{m}$ in $\mathbf{C}-\mathbf{E}$.

\section{MIST1 and Relationship to TFF2 in Normal Gastric Units}

In normal gastric units, isolated MIST1-positive cuboidal cells were present in the neck region. The majority of MIST1-positive cells were TFF2-negative (81\%; $n=491$ of 600 cells counted in the transition zone of three samples, see below), and additional spatial separation was achieved by interspersed MIST1-/TFF2- ${ }^{-}$parietal cells. On low-power magnification, this organization as well as separated foveolar-, neck- and basal zones could be appreciated (oxyntic tricolor; Figure 4A). Specifically, TFF2 was found in the neck/mid-zone of the gastric-unit and confined to GS-II- or MUC6-positive mucous neck cells (not shown) that were MIST1-negative (Figure 4C). Morphometric and quantitative analysis of the neck-base transition demonstrated an average height of 9.3 cells (range, 8 to $14 ; \sim 135$ to $225 \mu \mathrm{m} ; n=58$ gastric units in three samples) with an average of 1.8 cells (range, 0 to 5 ) colabeling with MIST1 and TFF2 (Figure 4D). This corresponded to $0.5 \%$ of cells in the glandular aspect of the gastric unit ( $n=1655$ cells counted). Similarly, individual cells in the upper aspect of the base showed rare MIST1 labeling chief cells with apical cytoplasmic TFF2 (Figure $4 \mathrm{E}$, asterisk). The separation of compartments with rare cells that demonstrated MIST1/TFF2 co-labeling was compatible with the separation observed in rodents and interpreted as immunophenotypic evidence for transitioning of mucous neck cells to chief cells. ${ }^{28,31}$

\section{MIST1 in Gastric Metaplasia}

We examined a total of 55 metaplastic lesions consisting of 21 resection samples (United States) and 34 TMAsamples (Korea). In resection specimens, with much more abundant tissue, diagnostic classification was based on the predominant pattern and we assigned 16 cases to the IM group, and classified five cases as SPEM. By definition, SPEM appears histologically as a basal band of pseudopyloric metaplasia (H\&E), PAS-, or TFF2 positivity (Figure 4B). In two of the five SPEM cases, extensive metaplasia was present and extended over multiple millimeters (Figure 4B) with either complete loss or only focal retention of standard chief cell markers (PGC or CBP1, eg, Figure 4F). Colocalization studies in SPEM demonstrated the absence of MIST1 in the basal aspects of these pyloric-type glands (Figure 4G). Cytologically, human SPEM cells are approximately triangular shape, with apical flocculent cytoplasm and a flat basally located, regular nucleus without prominent nucleolus or hyperchromasia; nuclear orientation is parallel to the basement membrane. We confirmed the absence of intestinal metaplasia by using the intestine-specific transcription factor CDX2; five of five cases of human SPEM were $\mathrm{CDX}^{-}$(Figure $4 \mathrm{H}$ ). In four of five cases there was significant gland-to-gland heterogeneity and we noted focal retained MIST1 labeling in $\sim 2$ of 50 gastric units (Figure $4 \mathrm{H}$, asterisk). Quantification in 500 glands (100 glands/case) demonstrated that this pattern of focal MIST1 positivity was more common than initially appreciated, with a total of 70 glands (14\%) with MIST1/TFF2 co-labeling ( $n=8,9,12,17$, and 24 affected glands; range, $8 \%$ to $24 \%$ ). From experimentally induced SPEM in mice, we know that basal co-labeling of TFF2 with MIST1 is present in the earliest forms of SPEM. Early MIST1 expression in experimental SPEM and lineage tracing studies indicate that SPEM in mice arises in part from chief cells. Thus, MIST1/TFF2 co-labeling in the base of the gastric unit is consistent with initial SPEM. ${ }^{11,31,68}$

Based on the strong association of SPEM/pyloric metaplasia with distinct immunophenotypic and morphological features (see below), we refer to these transitional SPEM lesions as "hybrid," an established term for gastric lesions with mixed features (see Discussion). Analysis of human MIST1/TFF2 expression in hybrid-SPEM shows at least three features different from established SPEM: (1) in $\sim 60 \%$ of hybrid-SPEM, basal TFF2 labeling is present in addition to a TFF2-positive neck zone (Figure 4, I-K). This is in contrast to established SPEM (which is morphologically identical to the term "pseudopyloric metaplasia"; 
Table 3. Evaluation of MIST1 Staining Pattern in Routine Biopsy Material

\begin{tabular}{|c|c|c|c|c|}
\hline Comparison of & Diagnosis & Diagnosis & Summary & Statistics \\
\hline $\begin{array}{l}\text { Gastritis } \\
\text { MIST1 }^{+} \\
\text {MIST1- }^{-}\end{array}$ & $\begin{array}{c}\text { Chronic active } \\
24 \\
1\end{array}$ & $\begin{array}{c}\text { Chronic inactive } \\
7 \\
2\end{array}$ & $\begin{array}{c}\text { Sum (\% all) } \\
31(91.2) \\
3(8.8)\end{array}$ & $\begin{array}{r}P \text { value } \\
0.164\end{array}$ \\
\hline $\begin{array}{l}\text { H. pylori status } \\
\text { MIST1 } 1^{+} \\
\text {MIST1- }^{-}\end{array}$ & $\begin{array}{l}\text { Positive } \\
17 \\
1\end{array}$ & $\begin{array}{r}\text { Negative } \\
14 \\
2\end{array}$ & $\begin{array}{c}\text { Sum ( } \% \text { all) } \\
31(91.2) \\
3(8.8)\end{array}$ & $\begin{array}{r}P \text { value } \\
0.59\end{array}$ \\
\hline $\begin{array}{l}\text { Chief cell pattern } \\
\text { (Diagnosis) } \\
\text { MIST1 }^{+} / \text {TFF2- (Normal) } \\
\text { MIST1 }^{+} / \text {TFF2 }^{+} \text {(hybrid-SPEM) } \\
\text { MIST1 }^{-} / \text {TFF2 }^{+} \text {(SPEM/PM) }\end{array}$ & $\begin{array}{r}\mathrm{CBP}^{+} / \mathrm{TFF}^{-} \\
\text {(Normal) }^{-} \\
21 \\
0 \\
0\end{array}$ & $\begin{array}{c}\mathrm{CBP}^{+} / \mathrm{TFF}^{+} \\
\text {(hybrid-SPEM) } \\
0 \\
10 \\
1^{*}\end{array}$ & $\begin{array}{c}\mathrm{CBP}^{-} / \mathrm{TFF}^{+} \\
\text {(SPEM) } \\
0 \\
0 \\
2\end{array}$ & Cohen's Kappa \\
\hline $\begin{array}{l}\text { H. pylori status } \\
{\text { MIST } 1^{+} / \text {TFF2 }^{-} \text {(Normal) }}^{\text {MIST } 1^{+} / \text {TFF2 }^{+} \text {(hybrid-SPEM) }}\end{array}$ & $\begin{array}{c}\text { Positive (+ previous) } \\
8(9) \\
7(9)\end{array}$ & $\begin{array}{c}\text { Negative (- previous) } \\
13(12) \\
3(1)\end{array}$ & $\begin{array}{c}\text { Sum (\% all) } \\
21 \\
10\end{array}$ & $\begin{array}{c}P \text { value (previous) } \\
0.13(0.02)\end{array}$ \\
\hline
\end{tabular}

Summary of evaluation performed on 34 consecutive oxyntic biopsy samples assessed for inflammatory activity (gastritis) and $H$. pylori status. TFF2/CBP1 pattern correlated with MIST1/TFF2 pattern. There is no significant association of current $H$. pylori status with hybrid SPEM; however, when prior $\mathrm{H}$. pylori infections are accounted for (in parentheses), a trend is noted (ie, indicative of regression; see Discussion and Figure 8B).

${ }^{*}$ A discrepant case.

Figure 4B) where the TFF2-positive neck zone is lost. (2) TFF2 labeling in MIST1+ ${ }^{+}$-chief cells occurs without complete extension of the existing TFF2 ${ }^{+}$-neck zone toward the base of the gastric unit (Figure 4, I and J, asterisk, K). Thus, $\mathrm{MIST}^{+} / \mathrm{TFF}^{-}$cells are often observed side-by-side or at the base of hybrid-SPEM lesions $\left(\mathrm{MIST}^{+} / \mathrm{TFF}^{+}\right.$). (3) In one of the five cases, the neck-zone of individual glands overlying hybrid-SPEM lesions showed co-labeling of cone-shaped, vaguely vertical or horizontal oriented MIST1-positive nuclei with apical TFF2 expression (Figure 4, M-O); this pattern is not observed in SPEM. Despite these differences, similarities of hybrid-SPEM with SPEM are as follows: (1) both occur as unitary lesions interspersed with glands that demonstrate a different expression pattern (Figure 4, I and K); (2) both are CDX2-negative (Figure 4L); and (3) both can be identified by routine H\&E (example of hybrid-SPEM, Figure 4P) or PAS staining (not shown).

We evaluated the feasibility of hybrid-SPEM assessment in 38 consecutive samples obtained in surgical pathology practice. Additional sectioning (for confirmation of oxyntic origin [chromogranin/gastrin] and assessment of $H$. pylori status [by IHC/Steiner stain]) or poor orientation of the sample (sectioning parallel to the luminal surface; $n=2$ ) precluded definitive assessment in four cases, and we determined the analytical sensitivity in the biopsy set as $89 \%$ ( $n=$ 34 of 38). When assessed by MIST1 or CBP1 staining in combination with TFF2 (Figure 5), 21 cases showed normal and 13 abnormal staining patterns (Table 3C). There was almost perfect agreement when double-stains were compared microscopically (Figure 5; Table 3C: $\kappa=0.9604$ ). Surprisingly, hybrid-SPEM was identified at least focally in nearly a third of the biopsies (Table $3 \mathrm{C}$ ) and in two of three samples with pyloric metaplasia (confirmed by H\&E and $\mathrm{IHC}$; Figure 5, D and H). The median follow-up time for the biopsy samples was 3.7 years (range, 0 to 4.7 years; average: 2.9) and six patients died. After exclusion of 16 patients without follow-up biopsy, the clinicopathologic features of hybrid-metaplastic samples were compared with those from patients with normal $\mathrm{MIST}^{+} / \mathrm{TFF} 2^{-}$pattern. In the latter ( $n=11$; median follow-up time: 3.67$)$ there was one patient with previous history of $H$. pylori gastritis, and one patient developed low-grade B-cell lymphoma $(+3.9$ months). In the hybrid metaplasia group ( $\mathrm{MIST}^{+} / \mathrm{TFF}^{+}$; $n=7$; median follow-up time: 3.9), two patients had a history of $H$. pylori gastritis, one of chronic nonspecific gastritis ( -12 months prior), one patient subsequently developed atrophic gastritis (+33 months), and another developed a gastric ulcer (+65.5 months). Although follow-up was limited, there was no difference in terms of average age, sex, or association with $H$. pylori (Table 3D) when hybrid SPEM was compared with the normal TFF2/MIST1 expression pattern. However, when we included prior $\mathrm{H}$. pylori status, there was a significant association of hybrid SPEM with previous or current $H$. pylori positivity (Table 3D, brackets; $P=0.02$; Fischer's exact test).

Given the limited follow-up availability, the biopsy set was most useful in illustrating practical feasibility of using these markers for assessment of differentiation state. TFF2 illustrated expansion of the neck cell compartment (Figure 5, C, $F$, and $G$ ), and ectopic expression at the base of oxyntic units (Figure 5, D and $\mathrm{H}$ ) indicated pseudopyloric metaplasia (SPEM). MIST1 was particularly advantageous as a nuclear stain that provided better contrast with cytoplasmic TFF2 (Figure 5, E-H) than previously used cytoplasmic chief cell markers PGC (not shown) or CBP1 (Figure 5, A-D). Taken together our data indicate that atrophy with initial SPEM is characterized by re-expression of neck-cell (ie, chief cell progenitor) markers in MIST1-positive chief cells; findings identical to those observed in rodents.

$\mathrm{IM}$ is morphologically recognized by intestinalization of the gastric units (ie, goblet cells, brush border) and expression of CDX2 (the caudal-type homeobox gene, important in early differentiation and maintenance of intestinal epithelium). ${ }^{69-72}$ In the resection samples (United States) we included 16 cases of IM, most of which were MIST1 negative $(n=12 ; 75 \%)$. Similarly, the TMA-samples (Korea) showed complete absence of MIST1 in 28 of 

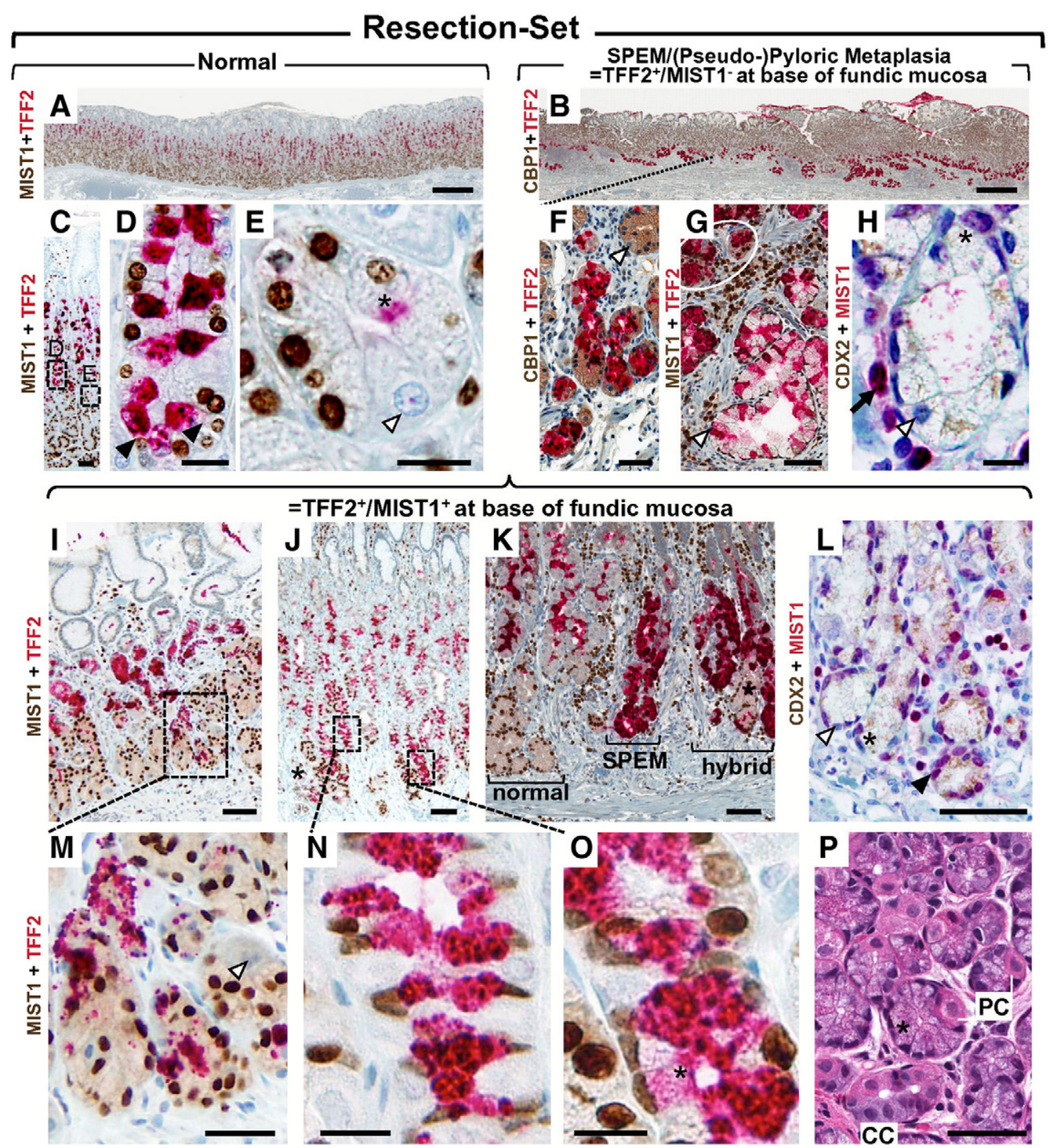

$=\mathrm{TFF}^{+} / \mathrm{MIST}^{+}$at base of fundic mucosa

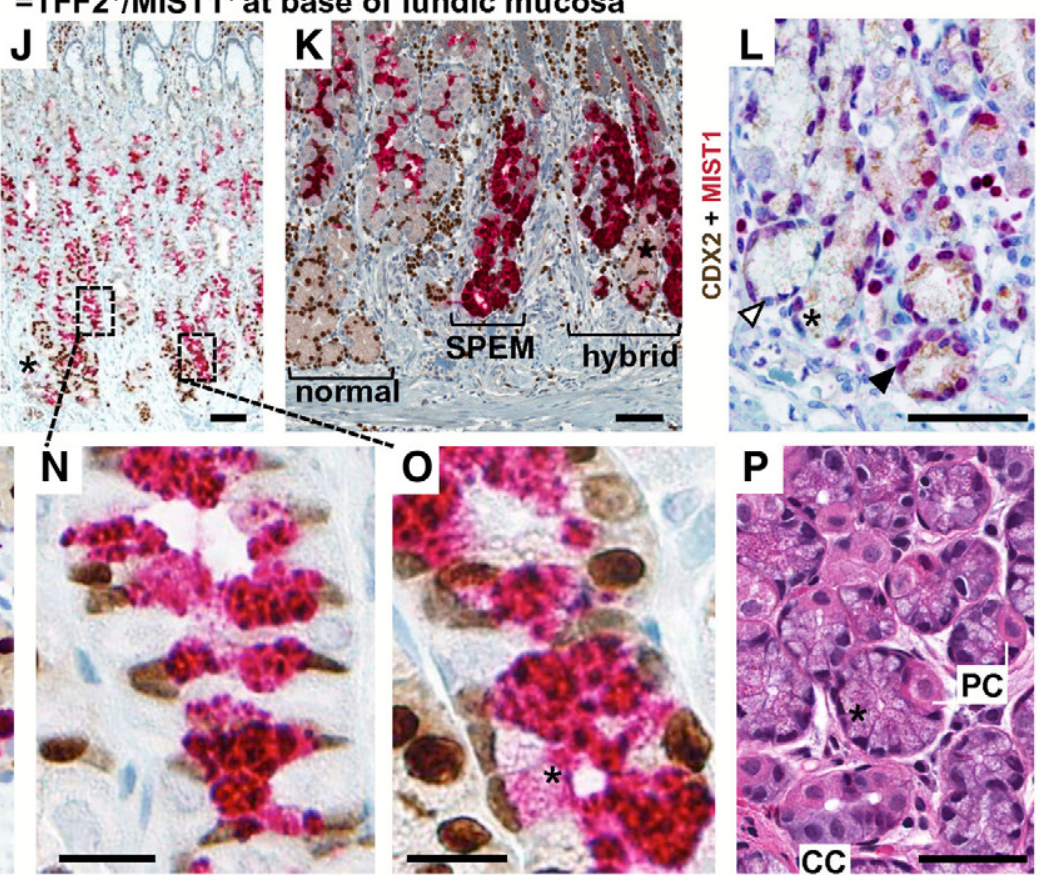

Figure 4. MIST1 in human SPEM. A: Normal oxyntic mucosa shows MIST1 (brown) at base, TFF2 (red) in neck-zone, and hematoxylin background stain (blue) in foveolar epithelium, appearing as well demarcated foveolar-, neck-, and basal zone (oxyntic tricolor). B: In SPEM, oxyntic mucosa shows reversal of the TFF2 (red) staining pattern; the latter is located at the base resulting in a red basal band on low-power magnification. C: Medium-power views show overlap of TFF2 ${ }^{+}$ (red) and MIST1 $^{+}$(brown) zones in the mid-glandular region (insets D and E). D: Despite spatial aggregation in the basal neck zone, TFF2 ${ }^{+}$(red) and MIST1 ${ }^{+}$ (brown) cells represent separate populations with very few cells demonstrating colocalization of both markers $(\sim 0.5 \% ; n=1655$ cells; arrowheads). E: The uppermost base shows abrupt loss of cytoplasmic TFF2-positivity (red, asterisk shows trace residual TFF2). Note the MIST1-negative parietal cell (open arrowhead). F: SPEM shows colocalization of CBP1 and TFF2 at the base of oxyntic-type mucosa. Note the lack of CBP1-positivity in parietal cells (open arrowhead). G: SPEM is MIST1-negative (open arrowhead). H: SPEM demonstrates absence of epithelial positivity for CDX2 (brown) and MIST1 (red). In 2 of 50 bases, individual cells with slight MIST1-positivity were noted (asterisk); MIST1-positive nucleus in lamina propria (plasma cell) serves as internal control (arrow). Morphologically, SPEM cells show a flocculent cytoplasm and predominantly basally located, flat nuclei ( $\sim 60 \%)$, whereas basally located round nuclei $(\sim 35 \%)$ or centrally located round nuclei $\left(\sim 5 \%\right.$; open arrowhead) are rarely observed. Note the oval and flat nuclear shape in the MIST1 ${ }^{+}$cell (asterisk). I: Medium-power magnification shows focal overlap of TFF2 (red) and MIST1 (brown) positivity at the base (inset M). Note TFF2 labeling in MIST1 ${ }^{+}$chief cells occurs without complete extension of the TFF2 compartment toward the base. J: Multifocal extension of TFF2 (red) into the MIST1-positive basal compartment (insets N and O). K: Unitary variation of MIST1 (brown) and TFF2 (red) presenting as normal pattern (left), SPEM (basal TFF2; middle), and hybrid-lesion (hybrid-SPEM) with multicellular colocalization of TFF2 ${ }^{+} / \mathrm{MIST}^{+}$(right). Note presence of TFF2 at the base with overlying MIST1 ${ }^{+} / \mathrm{TFF}^{-}{ }^{-}$chief cells (asterisk). L: Hybrid-SPEM is CDX2-negative and shows multifocal retention of MIST1 staining (arrowhead) adjacent to MIST1-negative nuclei (open arrowhead). Note flattened MIST1-negative nuclei (asterisk) and round to oval MIST1+ nuclei (red). M: High-power magnification of hybrid lesion (I) shows cytoplasmic TFF2 in MIST1-positive chief-cells. Note MIST1-negative parietal cells (open arrowhead). N: High-power magnification of upper base (J) shows cytoplasmic TFF2 in MIST1-positive cells (observed very focally in one of five cases) wedged in between MIST1-negative parietal cells. O: High-power magnification of base (J) shows MIST1 ${ }^{+} / \mathrm{TFF}^{+}{ }^{+}$-coexpressing cells with round to flattened nuclei (asterisk). P: H\&E-stained sections of oxyntic-type mucosa show normal chief cells (CC) and normal parietal cells (PC) admixed with glandular epithelial cells that show hybrid metaplasia. H\&E features are the flocculent cytoplasm (distinct from CC) and basally located oval to flat nuclei (asterisk). Scale bars $=500 \mu \mathrm{m}$ in $\mathbf{A}$ and $\mathbf{B} ; 50 \mu \mathrm{m}$ in $\mathbf{C}, \mathbf{F}, \mathbf{G}, \mathbf{P}$, and $\mathbf{M} ; 20 \mu \mathrm{m}$ in $\mathbf{D}, \mathbf{E}, \mathbf{H}, \mathbf{N}$, and $\mathbf{O}$; and $100 \mu \mathrm{m}$ in $\mathbf{I}, \mathbf{J}, \mathbf{K}$, and $\mathbf{L}$. 


\section{Biopsy-Set}
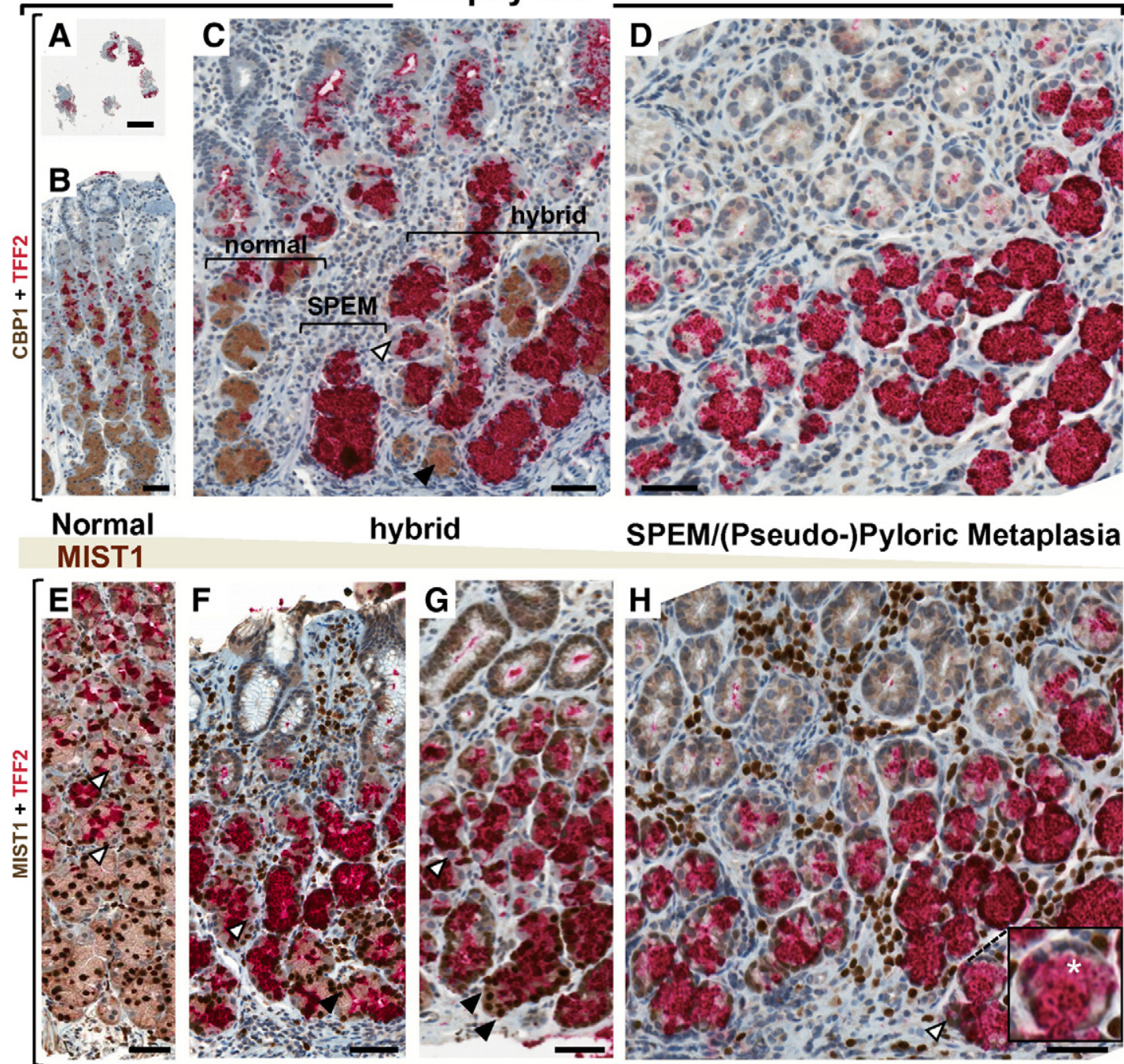

Figure 5. MIST1 in routine biopsy material. A: Overview, illustrating limited sampling and orientation of typical biopsy specimen. B: Normal oxyntic-type mucosa shows separation of CBP1-positive chief cells (brown) from TFF2-positive neck cells (red) and double-negative parietal- and foveolar cells (pale blue, hematoxylin). C: Mixture of normal (left), SPEM (middle), and hybrid-SPEM lesion (right). The latter shows admixture with basally located TFF2 ${ }^{-} / \mathrm{CBP}^{+}{ }^{+}$cells (arrowhead). Note the presence of parietal cells (open arrowhead). D: Band-like basal TFF2 expression (red) in SPEM without evidence of distinct areas of CBP1-positivity. E: Normal oxyntic-type mucosa with separate TFF2 (red) and MIST1 (brown) compartments in neck and base, respectively. Note MIST1- ${ }^{-}$TFF2 $^{-}$ parietal cells (open arrowheads). F and G: Two examples of hybrid-SPEM with different census of MIST1 ${ }^{+} / \mathrm{TFF}^{+}$chief-cells $\left(\mathrm{F}<\mathrm{G}\right.$ ); cytoplasmic TFF2 ${ }^{+}$(red) is localized in cells with nuclear MIST1 (brown; arrowheads). Note MIST1 ${ }^{-} /$TFF$^{-}$parietal cells (open arrowheads). H: SPEM shows band-like basal TFF2-positivity (red). Note the absence of isolated MIST1 ${ }^{+} / \mathrm{TFF}^{-}{ }^{-}$cells on the right (open arrowhead) and the mostly flat, basal nuclei (inset, asterisk). Scale bars $=1 \mathrm{~mm}$ in $\mathbf{A} ; 50 \mu \mathrm{m}$ in $\mathbf{B}-\mathbf{H}$

34 samples with IM (= 82\%; Figure $6, \mathrm{~A}-\mathrm{C})$. In the remaining 10 samples ( $n=4$ United States; 6 Korea), individual gastric units were partially intestinalized and demonstrated focal preservation of MIST1 (scored as $\mathrm{MIST}_{1}^{+}$; Figure 6D). In the cases with partial intestinalization, we observed (1) preservation of MIST1 at the base of an otherwise intestinalized gastric unit (Figure 6D); (2) presence of co-labeled (MIST1/CDX2) nuclei in proximity to MIST1-only and CDX2-only labeling nuclei at the base (Figure 6, F-J); or (3) presence of MIST1 ${ }^{+}$nuclei interspersed with $\mathrm{CDX} 2^{+}$nuclei at the base of the gastric unit (Figure 6, I and J). Architecturally, and similar to SPEM, the intestinalized glands demonstrated gland-togland heterogeneity (Figure 6, D and E) with often alternating normal and metaplastic lesions. In contrast to SPEM, IM cells showed elongated and vertically oriented-per- pendicular to the basement membrane-nuclei (observed in $\sim 40 \%$ of $\mathrm{IM}$ ). Accordingly, the nuclei of hybrid IM $\left(\mathrm{MIST}^{+} / \mathrm{CDX}^{+}\right)$were elongated and oriented in a similar direction. We noted that columnar (MIST1$\mathrm{CDX}^{+}$) nuclei in the base were frequently interspersed by either round, basally located $\mathrm{MIST}^{+}{ }^{+}$nuclei or elongated $\mathrm{MIST}_{1}{ }^{+} / \mathrm{CDX}_{2}{ }^{+}$nuclei (Figure $6 \mathrm{~J}$ ). The findings are consistent with basal acquisition of CDX2 expression in MIST1-positive cells. Overall, we identified 8 of 50 IM cases (16\%), or, when including SPEM, 12 out of 55 metaplastic cases that were at least partially MIST1-positive (=21.8\%; Table 2). We never observed TFF2 colocalization with CDX2 (not shown). Based on these data, we surmised that presence of MIST1 is a useful marker of healthy gastric epithelial differentiation (ie, chief-cells) and, conversely, loss of MIST1 would be a molecular 

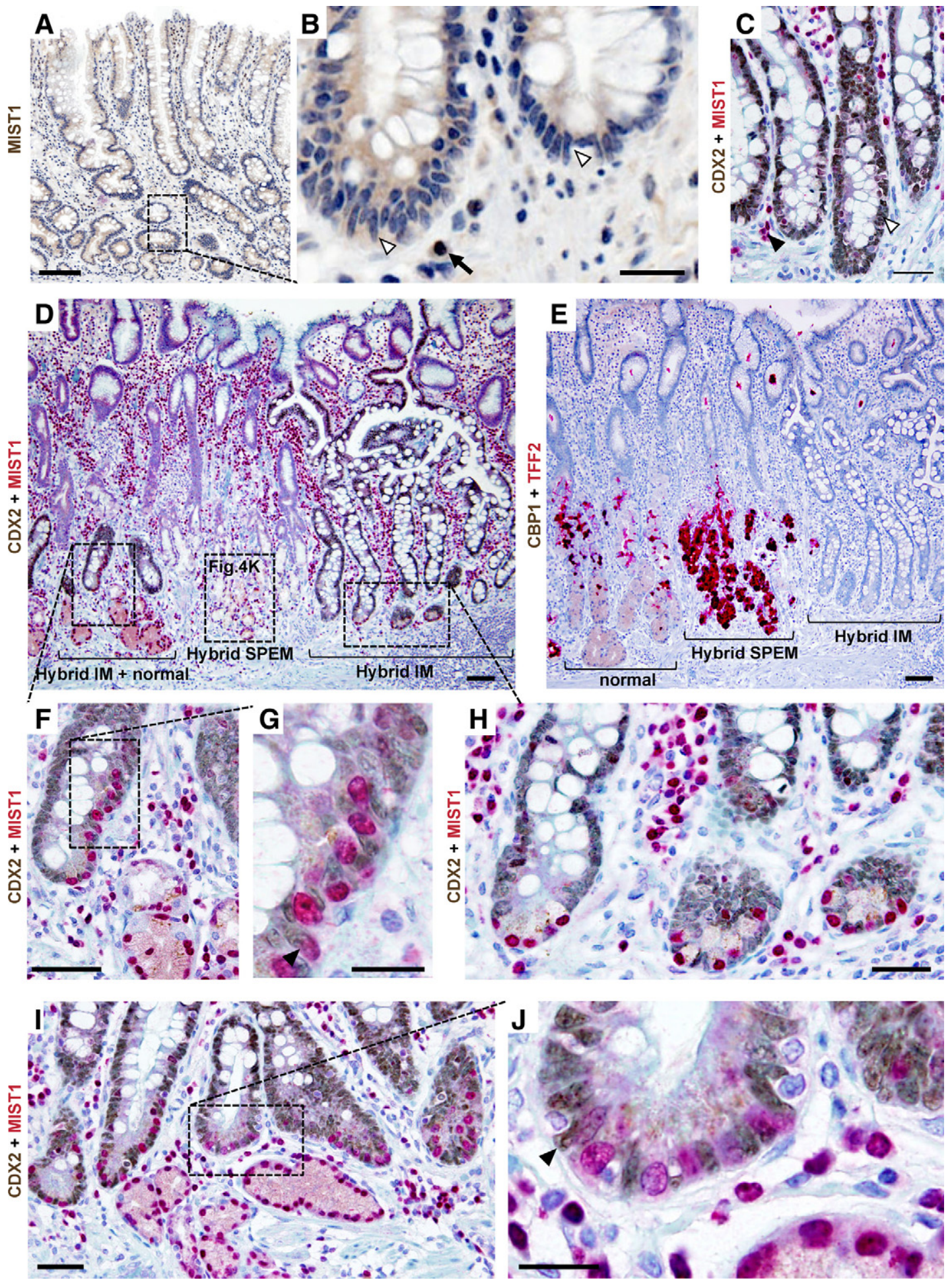

Figure 6. MIST1 in human IM. A: Low-power magnification of oxyntic-type mucosa replaced by goblet cell-rich intestinal metaplastic mucosa in a sample from a patient also given a diagnosis of chronic atrophic gastritis (inset B). MIST1 (brown). B: High-power magnification of intestinalized glands with goblet cells and absence of epithelial nuclear MIST1 positivity; MIST1 ${ }^{+}$plasma cells serve as internal control (arrow). Note the elongation of MIST1-negative nuclei (open arrowheads). C: CDX2-positive goblet cells (brown) are MIST1 (red) negative (open arrowhead). MIST1 ${ }^{+}$plasma cells serve as internal control (arrowhead). D: Low-power magnification shows unitary variation of CDX2 (brown) in normal (left), hybrid-SPEM (middle, Figure 4L), and IM (right); insets F, G, and $\mathbf{H}$ Note presence of at least focal MIST1 (red) at base of all units. E: Low-power magnification of subsequent section to D showing unitary variation of CBP1 (brown) in normal (left; IM not present on subsequent levels), hybrid-SPEM (middle), and IM (right). TFF2 (red) is absent in IM and the extent of TFF2 in hybrid-SPEM precludes definitive assessment of CBP1 (compare with region in D; Figure 4L). F: IM shows vertically oriented, elongated, CDX2 ${ }^{+}$nuclei, involving left half of the gastric gland, whereas right half shows predominantly oval to round MIST1 ${ }^{+}$nuclei (inset G). G: High-power magnification shows presence of $\mathrm{MIST}^{+} / \mathrm{CDX}^{+}$coexpressing nuclei (arrowhead). H: High-power magnification of basal aspects of otherwise completely intestinalized units (D, CDX2-positive) demonstrating interspersed MIST1-expressing chief cells (red). I: Medium-power magnification of normal chief-cells (MIST1 ${ }^{+}$, red) with overlying IM (CDX2 ${ }^{+}$

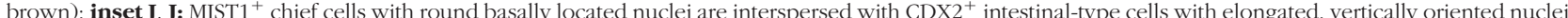
Note individual $\mathrm{MIST}^{+} / \mathrm{CDX}^{+}$nuclei (arrowhead). Scale bars $=100 \mu \mathrm{m}$ in $\mathbf{A}, \mathbf{D}$, and $\mathbf{E} ; 20 \mu \mathrm{m}$ in $\mathbf{B}, \mathbf{G}$, and $\mathbf{J}$; and $50 \mu \mathrm{m}$ in $\mathbf{C}, \mathbf{F}$, and $\mathbf{H}$. 

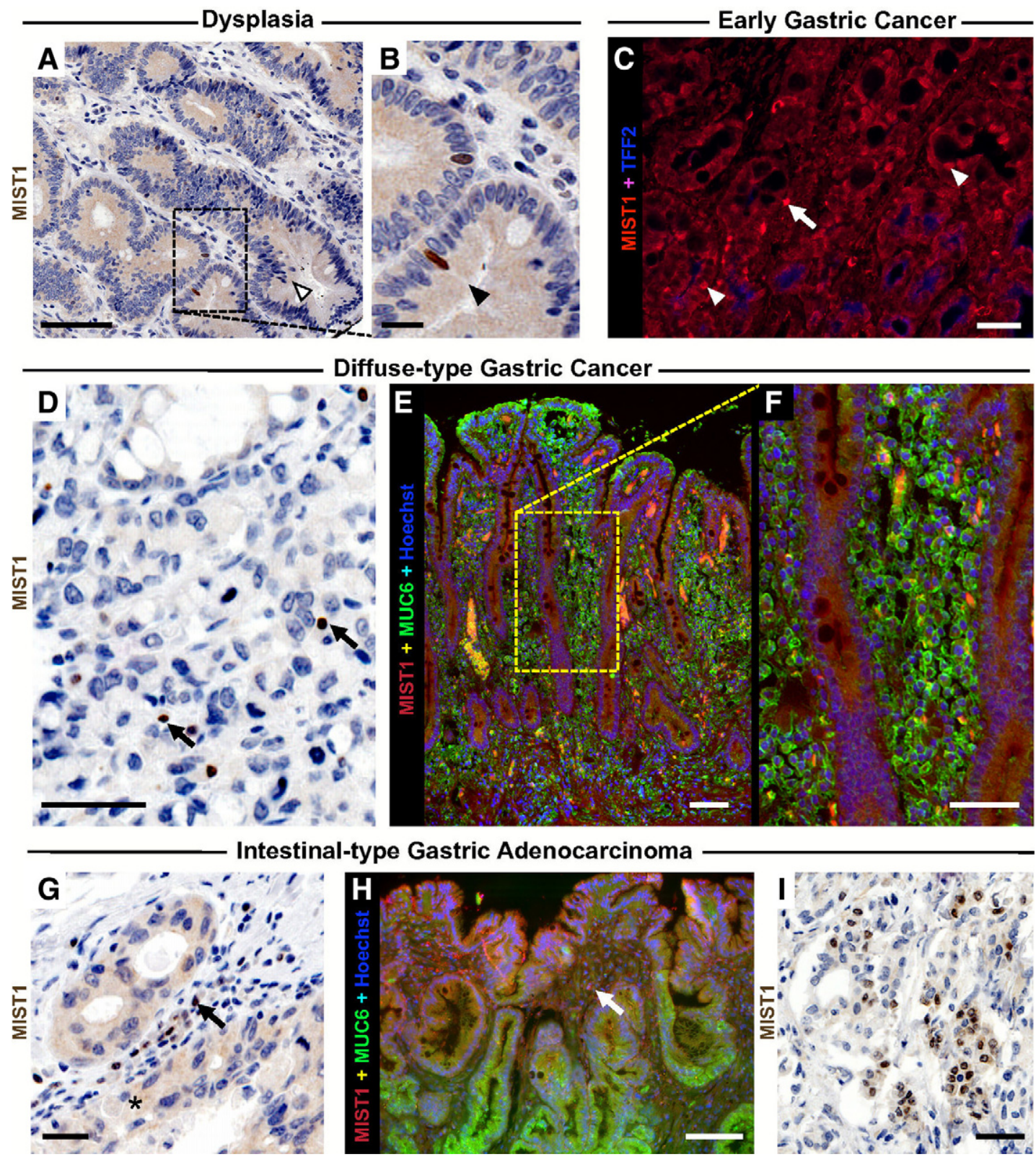

Figure 7. MIST1 in epithelial neoplasia. A: Medium-power magnification of low-grade intraepithelial neoplasia (dysplasia) demonstrates almost exclusively MIST1 $^{-}$nuclei open arrowhead; inset B. B: High-power magnification of low-grade dysplasia (A) shows focal preserved MIST1-expression (brown arrowhead); representing one of seven dysplastic lesions scored as MIST1-positive (Table 2). C: Medium-power magnification of so-called early-gastric carcinoma with focally retained epithelial MIST1-expression (arrowheads); MIST1 ${ }^{+}$plasma cells serve as internal control (arrow). D: Diffuse-type gastric adenocarcinomas are MIST1-negative; MIST1 ${ }^{+}$plasma cells serve as internal control (arrows). E: Low-power magnification of diffuse-type gastric adenocarcinoma shows infiltration of $\mathrm{MUC6}^{+}{ }^{-\mathrm{MIST}^{-}}{ }^{-}$tumor cells within the lamina propria (inset F). F: High-power magnification of MUC6 ${ }^{+} / \mathrm{MIST1}^{-}$tumor cells between preserved gastric units (scattered red cells are erythrocytes; note lack of nuclear stain). G: Example of moderately-differentiated intestinal type gastric adenocarcinoma without MIST1 expression. MIST1 ${ }^{+}$plasma cells serve as internal control (arrow). Note tumor cells show faint cytoplasmic staining (asterisk). H: MUC $6^{+} / \mathrm{MIST}^{-}$intestinal-type adenocarcinoma. I: Three adenocarcinomas showed multifocal MIST1-positivity, and had features consistent with chief-cell differentiation (so-called "chief-cell carcinomas"). Scale bars $=100 \mu \mathrm{m}$ in $\mathbf{A}, \mathbf{E}$, and $\mathbf{H} ; 20 \mu \mathrm{m}$ in $\mathbf{B}$; and $50 \mu \mathrm{m}$ in $\mathbf{C}, \mathbf{D}, \mathbf{F}$, and $\mathbf{G}$

indicator of progression to more advanced stages of aberrant epithelial differentiation.

\section{MIST1 in Epithelial Neoplasia}

Given gradual loss of MIST1 coincident with onset of either of the two common types of metaplasia, we hypothesized loss of MIST1 would characterize progression to neoplasia. We examined MIST1 staining in 281 dysplastic and carcinomatous lesions (Table 2). In the resection set, there was no epithelial MIST1 in the neoplastic lesions. We noted focal pencil-shaped MIST1-positive nuclei (on average one to three per dysplastic gland) in four of the low-grade and three of the high-grade intraepithelial neoplastic lesions in the TMA (dysplasia; Figure 7, A and B); these were scored as MIST1-positive. There was no significant difference between MIST1-positivity in low- versus high-grade intraepithelial neoplasia ( $P=0.68$; Fisher's 
exact test). We examined 73 early gastric adenocarcinomas ( $n=13$ United States; $n=60$ Korea) and found a single case with focally retained epithelial MIST1 (Figure $7 \mathrm{C}$ ). The 14 diffuse-type gastric adenocarcinomas showed no MIST1-positivity (Figure 7, D-F). Invasive (intestinal-type) adenocarcinoma was almost uniformly MIST1-negative; however, it was not uncommon to observe faint cytoplasmic positivity; the significance of this finding is uncertain (Figure 7, G-I). Two of the advanced (pT3NOMx; pT2N2Mx) and one early gastric carcinoma (pT1NOMx) showed multifocal MIST1-positivity. The patients were a 67-year-old man and a 55- and 74-year-old woman with 2.4-, 3.7-, and 1.5-cm tumors, respectively. The histomorphology and clinico-pathological characteristics were compatible with cases reported as extremely rare chief cell carcinomas, possibly explaining the presence of residual MIST1 expression. ${ }^{73}$

Taken together, our observations in the resection, TMA, and biopsy set indicate that (1) MIST1 was present in the vast majority of preneoplastic states (normal \& gastritis $\sim 80 \%$ ), whereas (2) MIST1 was lost in neoplasia. The separation effect between non-neoplasia and neoplasia (Figure $8 \mathrm{~A}$ ) is striking despite the stringent scoring criteria (ie, we defined "focal loss" as "MIST1-negative" versus "focal presence" as MIST1-positive).

\section{Discussion}

Here, we show that MIST1 is a reliable human chief cell marker that is lost early in the progressive stages of gastric carcinogenesis. We describe aberrant differentiation with either CDX2-labeling (IM) or TFF2-labeling (SPEM) in the MIST1 compartment and name these lesions hybrid metaplasias of either SPEM or IM subtypes. Our data confirm animal findings ${ }^{11,36}$ and indicate that metaplasia in humans is - at least in part-derived from the chief cell lineage. Therefore, we employ MIST1 to demonstrate a previously unrecognized role of human chief cells in gastric carcinogenesis with direct implications for assessment in diagnostic practice.

In gastric carcinogenesis, loss of parietal cells-and all parietal cell markers-in humans and in experimental animals correlates robustly with aberrant oxyntic-type differentiation in the early stages of carcinogenesis. However, the role of chief cells in human carcinogenesis has been neglected for several possible reasons. Chief cells are digestive-enzyme producing secretory factories that develop from mucous neck cells without an intermediate proliferating progenitor and have therefore generally been considered postmitotic and terminally differentiated. ${ }^{28,32,74}$ Despite progress in pyloric epithelial dynamics, ${ }^{75}$ in human oxyntic mucosa, all proliferation is thought to derive from stem cells in the isthmus as opposed to the base where chief cells reside. ${ }^{76}$ Possibly the most important reason for chief cell neglect is the lack of reliable human chief cell markers that would allow study of their differentiation during metaplasia and neoplasia. ${ }^{77}$

The data we present here, combined with previous studies in experimental animals, indicate that chief cells deserve considerably more attention. MIST1 immuno-

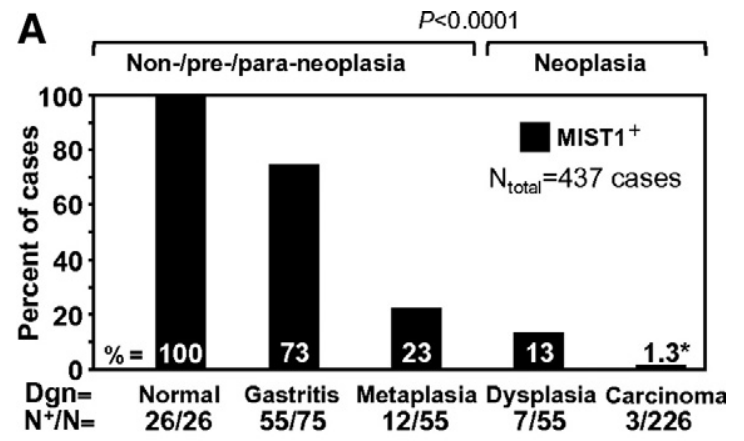

B
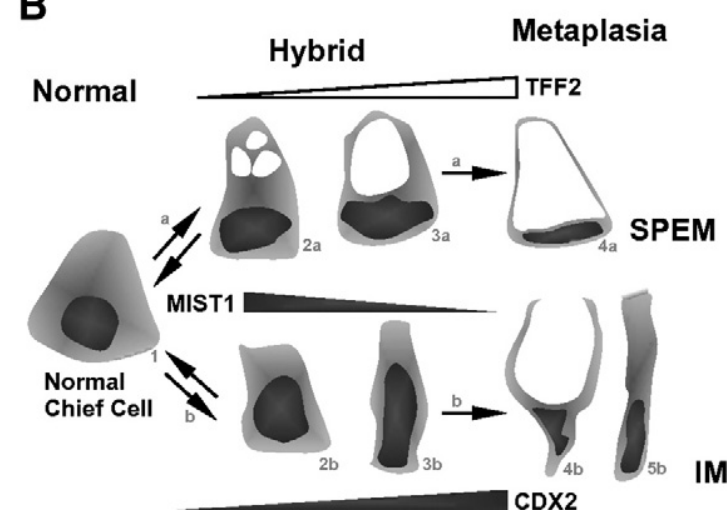

Figure 8. Summary of MIST1 as a marker for healthy chief-cells (A) and key features of hybrid metaplasia in SPEM and IM (B). A: Summary of MIST1 staining in the different diagnostic groups (Dgn) shows the proportion of staining $\left(\mathrm{N}^{+}\right)$expressed in percentage of the total number of cases per group (N). Asterisk denotes the three MIST1-positive carcinomas $(=1.3 \%)$ are considered chief-cell carcinomas (see Figure 7I). Cases here include 421 resection/TMA cases (Table 2) plus 34 cases in the biopsy set, but exclude 14 antral samples and four hyperplastic polyps. B: Cytological and immunophenotypic features of normal chief cells (1), hybrid metaplasia (2,3), SPEM (4a), and IM $(4 \mathrm{~b}, 5 \mathrm{~b})$ displayed as presumed morphological sequence but not necessarily linear progression (double arrows a, b indicate that hybrid lesions could also regress to normal). In all cells, nuclei are nondysplastic and basal nuclear position (polarity) is maintained, whereas apical differentiation and immunophenotype differs. Note elongated nuclei in SPEM are oriented parallel to the basement membrane (4a), whereas IM demonstrates vertical nuclei [displayed as a goblet cell (4b) and an absorptive enterocyte (5b; apical differentiation $=$ brush border)] .

staining illustrates the presence of human chief cells with aberrant differentiation (Figures 4O; 5, F and G; and 6, G and $\mathrm{J}$ ). These cells resemble those in mouse metaplasia models where chief cells have been shown to transdifferentiate into proliferative, metaplastic cells. ${ }^{11,31}$ Specifically, in gastrin knockout mice, after only 1 day of treatment with DMP-777 (a cell-permeant neutrophil elastase inhibitor), chief cells that are positive for both the murine chief cell marker intrinsic factor and Mist1 start re-expressing TFF2. ${ }^{11}$ The DMP-777 results are consistent with a relatively large literature showing that loss of parietal cells induces changes in chief cell lineage differentiation. ${ }^{35,78-81}$ Lineage tracing analysis using a pedigree of mice expressing Cre-recombinase knocked into the Mist1 locus ${ }^{82}$ crossed to an R26R reporter background (to trace cells where Cre has been expressed) has shown that loss of parietal cells directly induces chief cell dedifferentiation (Goldenring et al, unpublished observations). In humans, we observe the same phenomenon: that atrophy of parietal cells is coincident with corresponding changes in chief cell differentiation. Hybrid 
metaplastic lesions show co-labeling of MIST1 and TFF2 or CBP1 and TFF2 (Figures 4 and 5). Human cell-fate mapping is obviously not possible, thus, we correlated findings with histological stages and cytomorpology characterized in mouse models. ${ }^{11,31,36,54}$

We offer a simple model (Figure 8B) that encompasses the basic cytological and immunophenotypic features of the transitions we observe and propose the term hybrid metaplasias to identify the transitional states. The name and classification follows established terminology ${ }^{83,84}$ in the context of intraepithelial as well as invasive gastric neoplasia, where the mixed patterns of intestinal and gastric phenotypes are referred to as "hybrid-dysplasia" and "hybrid-carcinoma," respectively. ${ }^{6,7,85}$ Furthermore, the term "hybrid" avoids temporal connotations and is fitting since it refers to a mixed-lesional pattern in the MIST1 compartment that demonstrates either intestinal $\left(\mathrm{CDX2}^{+}\right.$, vertical nuclei, intestinal apical differentiation) or gastric features (= pseudopyloric metaplasia/SPEM: $\mathrm{TFF}^{+}$, horizontal nuclei, pyloric apical differentiation). Temporal connotations should be avoided as it remains to be determined whether hybrid lesions indicate progression to metaplasia or regression from metaplasia to normal pattern of differentiation; both may occur and exhibit the same hybrid features.

IM has been extensively studied as a premalignant condition, ${ }^{10,12,86-91}$ but despite wide acceptance, questions regarding the pathogenesis and relationship to cancer remain. For example, goblet cells by themselves are not reliable indicators of progression, ${ }^{13,92-96}$ and only certain subtypes show unequivocal association with carcinoma. ${ }^{52,88,97}$ As a result, the term paracancerous has been introduced to characterize IM lesions. ${ }^{10,98,99}$ The cellular origin of $I M$ in an organ otherwise devoid of intestinal-type cells poses certain experimental problems. ${ }^{5,12}$ Nonetheless, animal data support what we present here: strong indications for contributions of the chief cell lineage to the origin of intestinal metaplastic cells. Chronic gastritis and chronic atrophic gastritis are the lesions most commonly accompanied by IM. ${ }^{51}$ MIST1 staining assesses both lesions (the former via plasma cell staining, the latter indirectly via visualization of metaplastic changes in MIST1-positive chief cells and loss of MIST1-negative parietal cells). The demonstration of spatial heterogeneity in $\mathrm{IM}$ also validates animal findings ${ }^{37,72,99}$ and expands the concept of gland-to-gland heterogeneity, established in the context of human esophageal dysplasia, ${ }^{100}$ into the realm of metaplastic/ paracancerous lesions. Accordingly, CDX2+/MIST1+ hybrid nuclei likely represent an initial/intermediate stage of aberrant intestinal-like differentiation. As for SPEM, we cannot currently determine whether these lesions always represent progression toward IM or whether, in some cases, reversion of IM to normal tissue might occur with accumulation of hybrid forms. The very short follow-up time in our biopsy set imposes a substantial limitation that prevents us from speculating, though there was some trend in hybrid forms toward association with prior or current Helicobacter status. Overall, currently the strongest evidence for biological implications of hybrid-meta- plasias is their association with definitive metaplastic lesions (ie, implying a field-effect).

Differentiation of chief cells is achieved by progressive neck cell transcriptome alterations along the gland axis (eg, neck- to chief cell axis). ${ }^{28,31}$ Ultrastructurally, normal developing chief cells have to mount abundant basal rough-endoplasmic reticulum to built copious amounts of apical secretory vesicles, both features responsible for the granular appearance and characteristic pale purplegray appearance on routine H\&E stains (Figure 4P). In Mist1-ablated mice, the entire chief cell secretory apparatus is malformed as characterized by smaller secretory granules with reduced secretory capacity. ${ }^{28,31,34}$ Based on the restriction of Mist1 expression to mature chief cells, ${ }^{28}$ MIST1-positive chief cells in experimental mice give rise to TFF2-expressing, proliferative, metaplastic cells at the bases of gastric units as they slowly downregulate Mist1 expression ${ }^{11,31}$ (Goldenring and co-workers, unpublished observations). Although the exact mediators of initial to established metaplasia remain to be determined, our findings indicate maintenance of MIST1 (and resulting structural integrity) as one of the factors that prevents metaplastic progression in humans. This notion is supported by the propensity of $\mathrm{Mist}^{-1-}$ mice to develop pancreatic acinar to duct metaplasia and a presumptive role for MIST1 as a tumor suppressing factor in development of Pancreatic intraepithelial neoplasia (PanlN). ${ }^{82}$

Based on our findings in dysplasia and carcinoma, diagnostic application of MIST1 as a biomarker for normal (healthy) chief cells holds great promise. The concept of markers for normality can be referred to as the "canary in the coal mine" principle whereby the muting of a singing canary at the bottom of a coal mine signals a poisonous gas leak early enough to allow immediate evacuation of miners. ${ }^{101}$ Examples of this principle in diagnostic pathology include a variety of basal cell markers (eg, p63, K5, K14, SMA), the presence of which argues strongly against malignancy in a variety of lesions in the breast, ${ }^{102,103}$ salivary glands, ${ }^{104,105}$ and prostate. ${ }^{106-111}$ Although gastric chief cells are distinct from basal or myoepithelial cells (not present in gastrointestinal epithelium), MIST1 expression allows determination of an intact chief cell compartment on an individual gland basis. From a practical perspective, our demonstration of technical and practical feasibility in routine biopsy samples should allow prompt introduction into clinical diagnostics.

\section{Acknowledgments}

We thank Wayne Barnes for generous gifts including vectors, enzymes, riboprimers, and cells. We appreciate the support of the Washington University Digestive Diseases Research Core Center Bio-Bank and Clinical Data Core. Furthermore, we thank Autumn Watson, Vernetta Layton, Kevin Selle, Don Leahart, Kevin Keith, and Rodney Brown for expert histotechnical assistance, Jessie Hardges, Orlando Crisp, Byron Henderson, Melvin Stewart, Lisa Snipes from the autopsy service, Joan Rossi for microscope use; Walter Clermont, Stacey Yates, and 
Mike Isaacs for slide scanning and IT-support; and the support of Dr. James S. Lewis, Jr. and the research histology lab, as well as support of Dr. John Pfeifer, Dr. Elizabeth Brunt and Dr. Shashikant Kulkarni (Washington University/ Barnes-Jewish Hospital, Department of Pathology and Immunology). Thanks to Jessica Geahlen, Ivan Chebib, and Benjamin Capoccia for thoughtful discussions.

\section{References}

1. Parkin DM, Bray F, Ferlay J, Pisani P: Global cancer statistics, 2002. CA Cancer J Clin 2005, 55:74-108

2. Jarvi O, Lauren P: On the role of heterotopias of the intestinal epithelium in the pathogenesis of gastric cancer. Acta Pathol Microbiol Scand 1951, 29:26-44

3. Correa P: Human gastric carcinogenesis: a multistep and multifactorial process; First American Cancer Society Award Lecture on Cancer Epidemiology and Prevention. Cancer Res 1992, 52:6735-6740

4. Marshall BJ, Warren JR: Unidentified curved bacilli in the stomach of patients with gastritis and peptic ulceration. Lancet 1984, 1:1311-1315

5. Goldenring JR, Nam KT, Wang TC, Mills JC, Wright NA: Spasmolytic polypeptide-expressing metaplasia and intestinal metaplasia: time for reevaluation of metaplasias and the origins of gastric cancer. Gastroenterology 2010, 138:2207-2210

6. Park do Y, Srivastava A, Kim GH, Mino-Kenudson M, Deshpande V, Zukerberg LR, Song GA, Lauwers GY: CDX2 expression in the intestinal-type gastric epithelial neoplasia: frequency and significance. Mod Pathol 2010, 23:54-61

7. Park do Y, Srivastava A, Kim GH, Mino-Kenudson M, Deshpande V, Zukerberg LR, Song GA, Lauwers GY: Adenomatous and foveolar gastric dysplasia: distinct patterns of mucin expression and background intestinal metaplasia. Am J Surg Pathol 2008, 32:524-533

8. Kakinoki R, Kushima R, Matsubara A, Saito $Y$, Okabe H, Fujiyama $Y$, Hattori T: Re-evaluation of histogenesis of gastric carcinomas: a comparative histopathological study between Helicobacter pylorinegative and H. pylori-positive cases. Dig Dis Sci 2009, 54:614-620

9. Kawachi H, Takizawa T, Eishi Y, Shimizu S, Kumagai J, Funata N, Koike M: Absence of either gastric or intestinal phenotype in microscopic differentiated gastric carcinomas. J Pathol 2003, 199:436-446

10. Hattori T: Development of adenocarcinomas in the stomach. Cancer 1986, 57:1528-1534

11. Nozaki K, Ogawa M, Williams JA, Lafleur BJ, Ng V, Drapkin RI, Mills JC, Konieczny SF, Nomura S, Goldenring JR: A molecular signature of gastric metaplasia arising in response to acute parietal cell loss. Gastroenterology 2008, 134:511-522

12. Weis VG, Goldenring JR: Current understanding of SPEM and its standing in the preneoplastic process. Gastric Cancer 2009, 12:189-197

13. Schmidt PH, Lee JR, Joshi V, Playford RJ, Poulsom R, Wright NA, Goldenring JR: Identification of a metaplastic cell lineage associated with human gastric adenocarcinoma. Lab Invest 1999, 79:639-646

14. Houghton J, Stoicov C, Nomura S, Rogers AB, Carlson J, Li H, Cai X, Fox JG, Goldenring JR, Wang TC: Gastric cancer originating from bone marrow-derived cells. Science 2004, 306:1568-1571

15. Okumura T, Wang SS, Takaishi S, Tu SP, Ng V, Ericksen RE, Rustgi AK, Wang TC: Identification of a bone marrow-derived mesenchymal progenitor cell subset that can contribute to the gastric epithelium. Lab Invest 2009, 89:1410-1422

16. Capoccia BJ, Huh WJ, Mills JC: How form follows functional genomics: gene expression profiling gastric epithelial cells with a particular discourse on the parietal cell. Physiol Genomics 2009, 37:67-78

17. Pin CL, Bonvissuto AC, Konieczny SF: Mist1 expression is a common link among serous exocrine cells exhibiting regulated exocytosis. Anat Rec 2000, 259:157-167

18. D'Amour KA, Agulnick AD, Eliazer S, Kelly OG, Kroon E, Baetge EE:
Efficient differentiation of human embryonic stem cells to definitive endoderm. Nature Biotechnol 2005, 23:1534-1541

19. Elia G, Chinery R, Hanby AM, Poulsom R, Wright NA: The production and characterization of a new monoclonal antibody to the trefoil peptide human spasmolytic polypeptide. Histochem J 1994 26:644-647

20. Bunnett NW, Goldstein SM, Nakazato P: Isolation of a neuropeptidedegrading carboxypeptidase from the human stomach. Gastroenterology 1992, 102:76-87

21. Gottardi CJ, Caplan MJ: An ion-transporting ATPase encodes multiple apical localization signals. J Cell Biol 1993, 121:283-293

22. Dennis JL, Hvidsten TR, Wit EC, Komorowski J, Bell AK, Downie I, Mooney J, Verbeke C, Bellamy C, Keith WN, Oien KA: Markers of adenocarcinoma characteristic of the site of origin: development of a diagnostic algorithm. Clin Cancer Res 2005, 11:3766-3772

23. Reis CA, David L, Correa P, Carneiro F, de Bolos C, Garcia E, Mandel U, Clausen H, Sobrinho-Simoes M: Intestinal metaplasia of human stomach displays distinct patterns of mucin (MUC1, MUC2, MUC5AC, and MUC6) expression. Cancer Res 1999, 59:1003-1007

24. Mills JC, Syder AJ, Hong CV, Guruge JL, Raaii F, Gordon JI: A molecular profile of the mouse gastric parietal cell with and without exposure to Helicobacter pylori. Proc Natl Acad Sci USA 2001 98:13687-13692

25. Howard TA, Misra DN, Grove M, Becich MJ, Shao JS, Gordon M Alpers DH: Human gastric intrinsic factor expression is not restricted to parietal cells. J Anat 1996, 189 (Pt 2):303-313

26. Stave R, Brandtzaeg P: Immunohistochemical investigation of gastrin-producing cells ( $G$ cells): the distribution of $\mathrm{g}$ cells in resected human stomachs. Scand J Gastroenterol 1976, 11:705-712

27. Degorce F, Goumon Y, Jacquemart L, Vidaud C, Bellanger L, PonsAnicet $D$, Seguin $P$, Metz-Boutigue $M H$, Aunis $D$ : A new human chromogranin $\mathrm{A}(\mathrm{CgA})$ immunoradiometric assay involving monoclonal antibodies raised against the unprocessed central domain (145-245). Br J Cancer 1999, 79:65-71

28. Ramsey VG, Doherty JM, Chen CC, Stappenbeck TS, Konieczny SF, Mills JC: The maturation of mucus-secreting gastric epithelial progenitors into digestive-enzyme secreting zymogenic cells requires Mist1. Development 2007, 134:211-222

29. Leys CM, Nomura S, Rudzinski E, Kaminishi M, Montgomery E, Washington MK, Goldenring JR: Expression of Pdx-1 in human gastric metaplasia and gastric adenocarcinoma. Hum Pathol 2006 37:1162-1168

30. Lee HJ, Nam KT, Park HS, Kim MA, Lafleur BJ, Aburatani H, Yang HK, Kim WH, Goldenring JR: Gene expression profiling of metaplastic lineages identifies $\mathrm{CDH} 17$ as a prognostic marker in early-stage gastric cancer. Gastroenterology 2010 [Epub ahead of print]

31. Bredemeyer AJ, Geahlen JH, Weis VG, Huh WJ, Zinselmeyer BH, Srivatsan S, Miller MJ, Shaw AS, Mills JC: The gastric epithelia progenitor cell niche and differentiation of the zymogenic (chief) cell lineage. Dev Biol 2009, 325:211-224

32. Karam SM, Leblond CP: Dynamics of epithelial cells in the corpus of the mouse stomach. III Inward migration of neck cells followed by progressive transformation into zymogenic cells. Anat Rec 1993, 236:297-313

33. Hanby AM, Poulsom R, Playford RJ, Wright NA: The mucous neck cell in the human gastric corpus: a distinctive, functional cell lineage. J Pathol 1999, 187:331-337

34. Tian X, Jin RU, Bredemeyer AJ, Oates EJ, Blazewska KM, McKenna CE, Mills JC: RAB26 and RAB3D are direct transcriptional targets of MIST1 that regulate exocrine granule maturation. Mol Cell Biol 2010, 30:1269-1284

35. Nam KT, Varro A, Coffey RJ, Goldenring JR: Potentiation of oxyntic atrophy-induced gastric metaplasia in amphiregulin-deficient mice. Gastroenterology 2007, 132:1804-1819

36. Nomura S, Baxter T, Yamaguchi H, Leys C, Vartapetian AB, Fox JG, Lee JR, Wang TC, Goldenring JR: Spasmolytic polypeptide expressing metaplasia to preneoplasia in $\mathrm{H}$. felis-infected mice. Gastroenterology 2004, 127:582-594

37. Yoshizawa N, Takenaka Y, Yamaguchi H, Tetsuya T, Tanaka H, Tatematsu M, Nomura S, Goldenring JR, Kaminishi M: Emergence of spasmolytic polypeptide-expressing metaplasia in Mongolian gerbils infected with Helicobacter pylori. Lab Invest 2007, 87:12651276

38. Huh WJ, Mysorekar IU, Mills JC: Inducible activation of Cre recom- 
binase in adult mice causes gastric epithelial atrophy, metaplasia and regenerative changes in the absence of "floxed" alleles. Am J Physiol Gastrointest Liver Physiol 2010, April 22, [Epub ahead of print]

39. Wang TC, Dangler CA, Chen D, Goldenring JR, Koh T, Raychowdhury R, Coffey RJ, Ito S, Varro A, Dockray GJ, Fox JG: Synergistic interaction between hypergastrinemia and Helicobacter infection in a mouse model of gastric cancer. Gastroenterology 2000, 118:36-47

40. McDonald SA, Greaves LC, Gutierrez-Gonzalez L, Rodriguez-Justo M, Deheragoda M, Leedham SJ, Taylor RW, Lee CY, Preston SL, Lovell M, Hunt T, Elia G, Oukrif D, Harrison R, Novelli MR, Mitchell I, Stoker DL, Turnbull DM, Jankowski JA, Wright NA: Mechanisms of field cancerization in the human stomach: the expansion and spread of mutated gastric stem cells. Gastroenterology 2008, 134:500-510

41. Barnes WM: PCR amplification of up to 35-kb DNA with high fidelity and high yield from lambda bacteriophage templates. Proc Natl Acad Sci USA 1994, 91:2216-2220

42. Barnes WM: Ribocloning: DNA Cloning and Gene Construction using PCR Primers Terminated with a Ribonucleotide. In PCR Primers: a laboratory manual. ch 29. Edited by CW Dieffenbach, GS Dveksler. New York, Cold Spring Harbor Laboratory, 2003, pp 441-450

43. Barnes WM: Streamlined Gene Assembly PCR. In PCR Primers: a laboratory manual. ch 33. Edited by CW Dieffenbach, GS Dveksler. New York, Cold Spring Harbor Laboratory, 2003, pp 475-482

44. Studier FW: Protein production by auto-induction in high density shaking cultures. Protein Expr Purif 2005, 41:207-234

45. Lennerz J, Krejci E, Bantle E, Lewis J, Jr: Abstracts and case studies from the College of American Pathologists 2008 Annual Meeting (CAP '08). Arch Pathol Lab Med 2008, 132:1475

46. Torbenson M, Abraham SC, Boitnott J, Yardley JH, Wu TT: Autoimmune gastritis: distinct histological and immunohistochemical findings before complete loss of oxyntic glands. Mod Pathol 2002, 15:102-109

47. Wang LH, Choi YL, Hua XY, Shin YK, Song YJ, Youn SJ, Yun HY, Park SM, Kim WJ, Kim HJ, Choi JS, Kim SH: Increased expression of sonic hedgehog and altered methylation of its promoter region in gastric cancer and its related lesions. Mod Pathol 2006, 19:675-683

48. Aaltonen LA, Hamilton SR; World Health Organization, International Agency for Research on Cancer: Pathology and genetics of tumours of the digestive system. Lyon, Oxford, IARC Press; Oxford University Press (distributor), 2000, pp 314

49. Hundahl SA, Phillips JL, Menck HR: The National Cancer Data Base Report on poor survival of U.S. gastric carcinoma patients treated with gastrectomy: Fifth Edition American Joint Committee on Cancer staging, proximal disease, and the "different disease" hypothesis. Cancer 2000, 88:921-932

50. Mills SE: Histology for pathologists. Philadelphia, Lippincott Williams \& Wilkins, 2007, xi, pp 1272

51. Odze RD, Goldblum JR: Surgical pathology of the Gl tract, liver biliary tract, and pancreas. Philadelphia, Saunders/Elsevier, 2009, xviii: pp 1368

52. Dixon MF, Genta RM, Yardley JH, Correa P: Classification and grading of gastritis: the updated Sydney System International Workshop on the Histopathology of Gastritis, Houston 1994. Am J Surg Pathol 1996, 20:1161-1181

53. Rugge M, Genta RM: Staging gastritis: an international proposal. Gastroenterology 2005, 129:1807-1808

54. Nomura S, Yamaguchi H, Ogawa M, Wang TC, Lee JR, Goldenring JR: Alterations in gastric mucosal lineages induced by acute oxyntic atrophy in wild-type and gastrin-deficient mice. Am J Physiol Gastrointest Liver Physiol 2005, 288:G362-G375

55. Rubio CA: My approach to reporting a gastric biopsy. J Clin Pathol 2007, 60:160-166

56. Lauwers GY, Srivastava A: Gastric preneoplastic lesions and epithelial dysplasia. Gastroenterol Clin North Am. 2007, 36:813-829, vi

57. Cadwell K, Liu JY, Brown SL, Miyoshi H, Loh J, Lennerz JK, Kishi C, Kc W, Carrero JA, Hunt S, Stone CD, Brunt EM, Xavier RJ, Sleckman BP, Li E, Mizushima N, Stappenbeck TS, Virgin HWt: A key role for autophagy and the autophagy gene Atg16/1 in mouse and human intestinal Paneth cells. Nature 2008, 456:259-263

58. Cella M, Fuchs A, Vermi W, Facchetti F, Otero K, Lennerz JK, Doherty JM, Mills JC, Colonna M: A human natural killer cell subset provides an innate source of IL-22 for mucosal immunity. Nature 2009, 457:722-725

59. Kim SH, Kook MC, Song HG: Optimal conditions for the retrieval of CD4 and CD8 antigens in formalin-fixed, paraffin-embedded tissues. J Mol Histol 2004, 35:403-408

60. Kim SH, Kook MC, Shin YK, Park SH, Song HG: Evaluation of antigen retrieval buffer systems. J Mol Histol 2004, 35:409-416

61. Pin CL, Rukstalis JM, Johnson C, Konieczny SF: The bHLH transcription factor Mist1 is required to maintain exocrine pancreas cell organization and acinar cell identity. J Cell Biol 2001, 155:519-530

62. Lennerz JK, Ruhle V, Ceppa EP, Neuhuber WL, Bunnett NW, Grady EF, Messlinger K: Calcitonin receptor-like receptor (CLR), receptor activity-modifying protein 1 (RAMP1), and calcitonin gene-related peptide (CGRP) immunoreactivity in the rat trigeminovascular system: differences between peripheral and central CGRP receptor distribution. J Comp Neurol 2008, 507:1277-1299

63. Cohen J: A coefficient of agreement for nominal scales. Educ Psychol Meas 1960, 20:37-46

64. Zhu L, Tran T, Rukstalis JM, Sun P, Damsz B, Konieczny SF: Inhibition of Mist1 homodimer formation induces pancreatic acinar-toductal metaplasia. Mol Cell Biol 2004, 24:2673-2681

65. Tran T, Jia D, Sun Y, Konieczny SF: The bHLH domain of Mistl is sufficient to activate gene transcription. Gene Expr 2007, 13: 241-253

66. McLellan AS, Langlands K, Kealey T: Exhaustive identification of human class II basic helix-loop-helix proteins by virtual library screening. Mech Dev 2002, 119 Suppl 1:S285-S291

67. Lemercier C, To RQ, Swanson BJ, Lyons GE, Konieczny SF: Mist1: a novel basic helix-loop-helix transcription factor exhibits a developmentally regulated expression pattern. Dev Biol 1997, 182 101-113

68. Goldenring JR, Nomura S: Differentiation of the gastric mucosa III. Animal models of oxyntic atrophy and metaplasia. Am J Physiol Gastrointest Liver Physiol 2006, 291:G999-G1004

69. Mallo GV, Rechreche H, Frigerio JM, Rocha D, Zweibaum A, Lacasa M, Jordan BR, Dusetti NJ, Dagorn JC, Iovanna JL: Molecular cloning, sequencing and expression of the mRNA encoding human $\mathrm{Cdx} 1$ and $\mathrm{Cdx} 2$ homeobox: down-regulation of $\mathrm{Cdx} 1$ and $\mathrm{Cdx} 2$ mRNA expression during colorectal carcinogenesis. Int $\mathrm{J}$ Cancer 1997, 74:35-44

70. Silberg DG, Swain GP, Suh ER, Traber PG: Cdx1 and cdx2 expression during intestinal development. Gastroenterology 2000, 119 961-971

71. Silberg DG, Sullivan J, Kang E, Swain GP, Moffett J, Sund NJ, Sackett SD, Kaestner KH: Cdx2 ectopic expression induces gastric intestinal metaplasia in transgenic mice. Gastroenterology 2002, 122:689-696

72. Mutoh H, Hakamata Y, Sato K, Eda A, Yanaka I, Honda S, Osawa H, Kaneko Y, Sugano K: Conversion of gastric mucosa to intestinal metaplasia in $\mathrm{Cdx}$-expressing transgenic mice. Biochem Biophys Res Commun 2002, 294:470-479

73. Tsukamoto $T$, Yokoi T, Maruta S, Kitamura M, Yamamoto $T$, Ban $\mathrm{H}_{\text {, }}$ Tatematsu M: Gastric adenocarcinoma with chief cell differentiation. Pathol Int 2007, 57:517-522

74. Ge YB, Ohmori J, Tsuyama S, Yang DH, Kato K, Miyauchi M, Murata $\mathrm{F}$ : Immunocytochemistry and in situ hybridization studies of pepsinogen C-producing cells in developing rat fundic glands. Cell Tissue Res 1998, 293:121-131

75. Barker N, Huch M, Kujala P, van de Wetering M, Snippert HJ, van Es $\mathrm{JH}$, Sato T, Stange DE, Begthel H, van den Born M, Danenberg E, van den Brink S, Korving J, Abo A, Peters PJ, Wright N, Poulsom R Clevers H: Lgr5(+ve) stem cells drive self-renewal in the stomach and build long-lived gastric units in vitro. Cell Stem Cell 2010, 6:25-36

76. Karam SM, Straiton T, Hassan WM, Leblond CP: Defining epithelia cell progenitors in the human oxyntic mucosa. Stem Cells 2003 21:322-336

77. Stemmermann GN, Samloff IM, Hayashi T: Pepsinogens I and II in carcinoma of the stomach: an immunohistochemical study. App Pathol 1985, 3:159-163

78. Li Q, Karam SM, Gordon JI: Diphtheria toxin-mediated ablation of parietal cells in the stomach of transgenic mice. J Biol Chem 1996, 271:3671-3676

79. Xiao C, Ogle SA, Schumacher MA, Orr-Asman MA, Miller ML, 
Lertkowit N, Varro A, Hollande F, Zavros Y: Loss of parietal cell expression of Sonic hedgehog induces hypergastrinemia and hyperproliferation of surface mucous cells. Gastroenterology 2010, 138:550-561

80. Jain RN, Al-Menhali AA, Keeley TM, Ren J, El-Zaatari M, Chen X, Merchant JL, Ross TS, Chew CS, Samuelson LC: Hip1r is expressed in gastric parietal cells and is required for tubulovesicle formation and cell survival in mice. J Clin Invest 2008, 118:2459-2470

81. Waghray M, Zavros Y, Saqui-Salces M, El-Zaatari M, Alamelumangapuram CB, Todisco A, Eaton KA, Merchant JL: Interleukin-1beta promotes gastric atrophy through suppression of sonic hedgehog. Gastroenterology 2010, 138:562-572

82. Shi G, Zhu L, Sun Y, Bettencourt R, Damsz B, Hruban RH, Konieczny SF: Loss of the acinar-restricted transcription factor Mist1 accelerates Kras-induced pancreatic intraepithelial neoplasia. Gastroenterology 2009, 136:1368-1378

83. Brown IS, Whiteman DC, Lauwers GY: Foveolar type dysplasia in Barrett esophagus. Mod Pathol 2010, 23:834-843

84. Seifert G, Donath K: Hybrid tumours of salivary glands: definition and classification of five rare cases. Eur $\mathrm{J}$ Cancer B Oral Oncol 1996, 32B:251-259

85. Kabashima A, Yao T, Sugimachi K, Tsuneyoshi M: Gastric or intestinal phenotypic expression in the carcinomas and background mucosa of multiple early gastric carcinomas. Histopathology 2000, 37:513-522

86. Morson BC: Carcinoma arising from areas of intestinal metaplasia in the gastric mucosa. Br J Cancer 1955, 9:377-385

87. Stemmermann GN, Hayashi T: Intestinal metaplasia of the gastric mucosa: a gross and microscopic study of its distribution in various disease states. J Natl Cancer Inst 1968, 41:627-634

88. Correa P: A human model of gastric carcinogenesis. Cancer Res $1988,48: 3554-3560$

89. Hattori T, Fujita S: Tritiated thymidine autoradiographic study on histogenesis and spreading of intestinal metaplasia in human stomach. Pathol Res Pract 1979, 164:224-237

90. Xia HH, Kalantar JS, Talley NJ, Wyatt JM, Adams S, Chueng K, Mitchell HM: Antral-type mucosa in the gastric incisura, body, and fundus (antralization): a link between Helicobacter pylori infection and intestinal metaplasia? Am J Gastroenterol 2000, 95:114-121

91. Mirza ZK, Das KK, Slate J, Mapitigama RN, Amenta PS, Griffel LH, Ramsundar L, Watari J, Yokota K, Tanabe H, Sato T, Kohgo Y, Das KM: Gastric intestinal metaplasia as detected by a monoclonal antibody is highly associated with gastric adenocarcinoma. Gut 2003, 52:807-812

92. Kim BW, Kim KM, Lee BI, Maeng LS, Choi H, Cho SH, Chae HS, Kim JK, Choi KY, Chung IS: Expression of trefoil peptides in the subtypes of intestinal metaplasia. Peptides 2004, 25:779-783

93. Mahajan D, Bennett AE, Liu X, Bena J, Bronner MP: Grading of gastric foveolar-type dysplasia in Barrett's esophagus. Mod Pathol 2010, 23:1-11

94. Nakamura T, Yao T, Kabashima A, Nishiyama $K$, Maehara $Y$, Tsuneyoshi M: Loss of phenotypic expression is related to tumour progression in early gastric differentiated adenocarcinoma. Histopathology 2005, 47:357-367

95. Odze RD: Update on the diagnosis and treatment of Barrett esoph- agus and related neoplastic precursor lesions. Arch Pathol Lab Med 2008, 132:1577-1585

96. Rucker-Schmidt RL, Sanchez CA, Blount PL, Ayub K, Li X, Rabinovitch PS, Reid BJ, Odze RD: Nonadenomatous dysplasia in barrett esophagus: a clinical, pathologic, and DNA content flow cytometric study. Am J Surg Pathol 2009, 33:886-893

97. Filipe MI, Munoz N, Matko I, Kato I, Pompe-Kirn V, Jutersek A Teuchmann S, Benz M, Prijon T: Intestinal metaplasia types and the risk of gastric cancer: a cohort study in Slovenia. Int J Cancer 1994 $57: 324-329$

98. World Health Organization: International statistical classification of diseases and related health problems. Geneva, World Health Organization, 2004

99. Tsukamoto T, Mizoshita T, Tatematsu M: Animal models of stomach carcinogenesis. Toxicol Pathol 2007, 35:636-648

100. Srivastava A, Hornick JL, Li X, Blount PL, Sanchez CA, Cowan DS, Ayub K, Maley CC, Reid BJ, Odze RD: Extent of low-grade dysplasia is a risk factor for the development of esophageal adenocarcinoma in Barrett's esophagus. Am J Gastroenterol 2007, 102:483-493

101. Page HP, Page AW: The World's Work. New York, Doubleday, Page \& Co., 1900, p 474

102. Barbareschi M, Pecciarini L, Cangi MG, Macri E, Rizzo A, Viale G, Doglioni C: p63, a p53 homologue, is a selective nuclear marker of myoepithelial cells of the human breast. Am J Surg Pathol 2001, 25:1054-1060

103. O'Hare MJ, Ormerod MG, Monaghan P, Lane EB, Gusterson BA: Characterization in vitro of luminal and myoepithelial cells isolated from the human mammary gland by cell sorting. Differentiation 1991 46:209-221

104. McHugh JB, Visscher DW, Barnes EL: Update on selected salivary gland neoplasms. Arch Pathol Lab Med 2009, 133:1763-1774

105. Seethala RR, Barnes EL, Hunt JL: Epithelial-myoepithelial carcinoma: a review of the clinicopathologic spectrum and immunophenotypic characteristics in 61 tumors of the salivary glands and upper aerodigestive tract. Am J Surg Pathol 2007, 31:44-57

106. Hameed O, Humphrey PA: Immunohistochemistry in diagnostic surgical pathology of the prostate. Semin Diagn Pathol 2005 22:88-104

107. Hameed O, Humphrey PA: Pseudoneoplastic mimics of prostate and bladder carcinomas. Arch Pathol Lab Med 2010, 134:427-443

108. Hameed O, Sublett J, Humphrey PA: Immunohistochemical stains for p63 and alpha-methylacyl-CoA racemase, versus a cocktail comprising both, in the diagnosis of prostatic carcinoma: a comparison of the immunohistochemical staining of 430 foci in radical prostatectomy and needle biopsy tissues. Am J Surg Pathol 2005, 29:579-587

109. Molinie V, Baumert H: New markers in prostate biopsies. Actas Urol Esp 2007, 31:1009-1024

110. Shah RB, Zhou M, LeBlanc M, Snyder M, Rubin MA: Comparison of the basal cell-specific markers, 34betaE12 and p63, in the diagnosis of prostate cancer. Am J Surg Pathol 2002, 26:1161-1168

111. van Leenders GJ, Aalders TW, Hulsbergen-van de Kaa CA, Ruiter DJ, Schalken JA: Expression of basal cell keratins in human prostate cancer metastases and cell lines. J Pathol 2001, 195:563-570 